\title{
SHALLOW SEISMIC STRATIGRAPHY BETWEEN THE CANNING RIVER AND DEMARCATION BAY, BEAUFORT SEA, ALASKA
}

By

S. C. Wolf, P.W. Barnes, D.M. Rearic, and Erk Reimnitz ${ }^{1}$

Open-File Report 86-582

This report is preliminary and has not been reviewed for conformity with U.S. Geological Survey editorial standards and stratigraphic nomenclature.

1U.S. Geological Survey, Menlo Park, California 
INTRODUCTION $\ldots \ldots \ldots \ldots \ldots \ldots \ldots \ldots \ldots \ldots \ldots \ldots \ldots \ldots \ldots \ldots \ldots \ldots \ldots \ldots \ldots \ldots \ldots \ldots \ldots, 1$

Physiography...................................... 4

Onshore Coastal Plain Physiography.................... 4

Offshore Physiography............................ 4

Seismic Data and Analysis............................ 5

Description and Significance of Acoustic Reflectors........... 5

Canning River to Barter Island...................... 5

Camden Bay Area................................ 7

Barter Island Area............................... 10

Barter Island to Demarcation Bay.................... 10

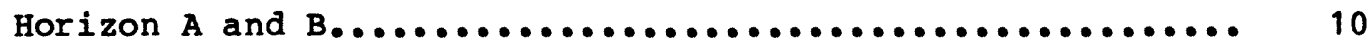

Horizon $A \ldots \ldots \ldots \ldots \ldots \ldots \ldots \ldots \ldots \ldots \ldots \ldots \ldots \ldots \ldots \ldots \ldots \ldots \ldots \ldots$

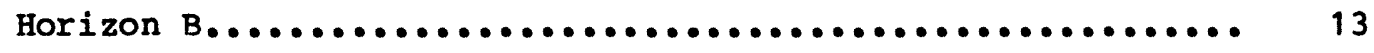

Units above Horizon B............................ 13

Youngest units including Holocene.................... 20

Acoustic ancmalies suggesting gas.................... 25

Areal Distribution and Analysis of Horizon A............. 25

Interpretation and Conclusions - Canning River to Barter

Island and Barter Island to Demarcation Bay............. 29

Table 1. Vessel log data for seismic tracklines completed exclusive of side-scan sonar....................... 3

References Cited..................................... 32 
Figure 1. Generalized geographic map showing location of rivers, mountain, bays, and lagoons mentioned in this report and an insert map showing location of this study in relation to a companion study by wolf and others, 1985

Figure 2. Location map of U.S. Geological Survey tracklines traversed in Canden Bay, Canning River-Barter Island area Beaufort Sea, Alaska (1971-1983).................. 6

Figure 3. Sea floor map showing apparent distribution and attitudes of each geologic unit in Camden Bay............

Figure 4. Contour map drawn on surface of horizon A'......... 9

Figure 5. Map showing subsurface structures north-west of Barter Island.

Figure 6. Location map of U.S. Geological Survey tracklines traversed in the Survey in the Barter Island to Demarcation Bay area, Beaufort Sea, Alaska during the period $1971-1983$

Figure 7. Representative seismic section for the area between Barter Island and Demarcation Bay in $40 \mathrm{~m}$ water depth along tracline 26-83 (fig. 2)...............

Figure 8. Uniboom data (line 34-81) and $7 \mathrm{kHz}$ data (line 33-81) north of Barter Island, Beaufort Sea, Alaska.........

Figure 9. Representative middle inner shelf $(15-25 \mathrm{~m})$ seismic reflection Profiles. Possible gas charged sediments occur in the lower profile (see fig. 6 for location).

Figure 10. Examples of $7 \mathrm{kHz}$ records showing seaward dipping reflectors that are truncated at the sea floor........

Figure 11. Sea floor map showing apparent distribution and attitudes of each geologic unit above horizon $B$ along the inner shelf...........................

Figure 12. Possible Holocene accumulations offshore.............

Figure 13. Maps showing seismic tracklines in Demarcation Bay and thickness of contours of Holocene(?) sediments (in meters) $\ldots \ldots \ldots \ldots \ldots \ldots \ldots \ldots \ldots \ldots \ldots \ldots \ldots \ldots \ldots \ldots \ldots \ldots \ldots \ldots$

Figure 14. LANDSAT imagery of Demarcation Bay, adjacent fans, and barrier islands..........................

Figure 15. Map showing trackline coverage and thickness of Holocene(?) sediment in Beaufort Lagoon, particularly Nuragapak Lagoon (see fig. 3) ................... 
Figure 16. Map showing areal distribution and depth below sea

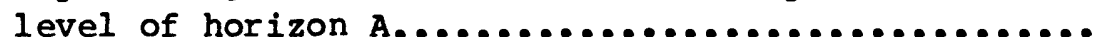

Figure 17. Location and orientation of profiles " $a^{\text {" }}$ and "b"

between Barter Island and Demarcation Bay.

Figure 18. Profiles " $\mathrm{a}$ " and "b" showing topographic gradient

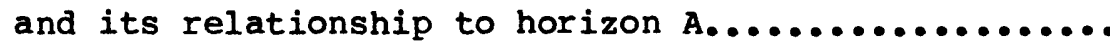

Figure 19. Generalized cross section from Canning River fan-delta through Flaxman Island to borehole 18 (from wolf and

others, 1985).................................. 


\title{
SHALLOW SEISMIC STRATIGRAPHY BETWEEN THE CANNING RIVER AND DEMARCATION BAY, BEAUFORT SEA, ALASKA
}

\author{
S.C. Wolf, P.W. Barnes, D.M. Rearic, and Erk Reimnitz
}

\section{INTRODUCTION}

The transgressive and regressive history of the sea along the arctic continental margin during glacial periods is poorly understood due to the limited number of arctic studies and the limited understanding of arctic marine geologic processes. Development of this history is needed to interpret the thermal and permafrost regime, to better understand past and future climatic trends, to assess the present stability of the coast and shelf sediments, and the potential for deposits of sand and gravel.

The following report provides a stratigraphic framework based on the interpretation of less than 50 meters of shallow seismic data. These sediments were deposited during Pleistocene and Holocene time on the inner shelf of the Beaufort Sea between the Canning River and the Canadian border, a shoreline distance of approximately 180 kilometers. The purpose of this study has been to obtain and interpret all available geophysical data, to develop an understanding of the geologic framework that operated during Quaternary time, and to describe the recent geologic history of the area. The report is an eastward extension of an earlier report by Wolf and others (1985) that describes the shallow seismic stratigraphy between Prudhoe Bay and the Canning River (see insert map fig. 1).

Geophysical data for this study were acquired along approximately 675 kilometers of tracklines, many of which extended 20 kilometers seaward from the coast (fig. 1). Uniboom and Geopulse seismic systems were used for the shallow seismic surveys. These systems penetrated as deep as 50 meters beneath the sea floor in some areas. Raytheon RTT 1000 and Innerspace bathymetric profiling systems provided bathymetric data as well as high frequency $(7 \mathrm{kHz})$ subbottom seismic data. Side-scan sonar data, although not a significant part of this report, were acquired with an EG\&G model $259-4100 \mathrm{kHz}$ system and a Klein 531T, 100 and $500 \mathrm{kHz}$ system which incorporated a subbottom profiler and microprofiler. A listing of data from vessel logs are shown in Table 1.

The primary reason for the apparently random line patterns is that field work objectives and priorities varied from one year to another, as did the sea ice distribution. The latter is a factor that commonly dictates where and how a particular line can be run. Furthermore, seismic profiles represent only a fraction of the data gathered. Often specific study topics were pursued, involving such additional techniques as underwater photography and video recording, diving operations, sediment and water sampling, coring, ice gouge studies and repetitive surveys of certain lines with side scan and $7 \mathrm{kHz}$ equipment. Furthermore, many tracklines simply represent transit lines from one study site to another, on which only bathymetric data were taken. Reports of results of other studies may be found in Barnes and others (1980), Kempema and others (1981), Reimnitz and others (1982), Barnes and others (1982), Kempema and others (1983), Minkler and others (1982), and Barnes and others (1983). 


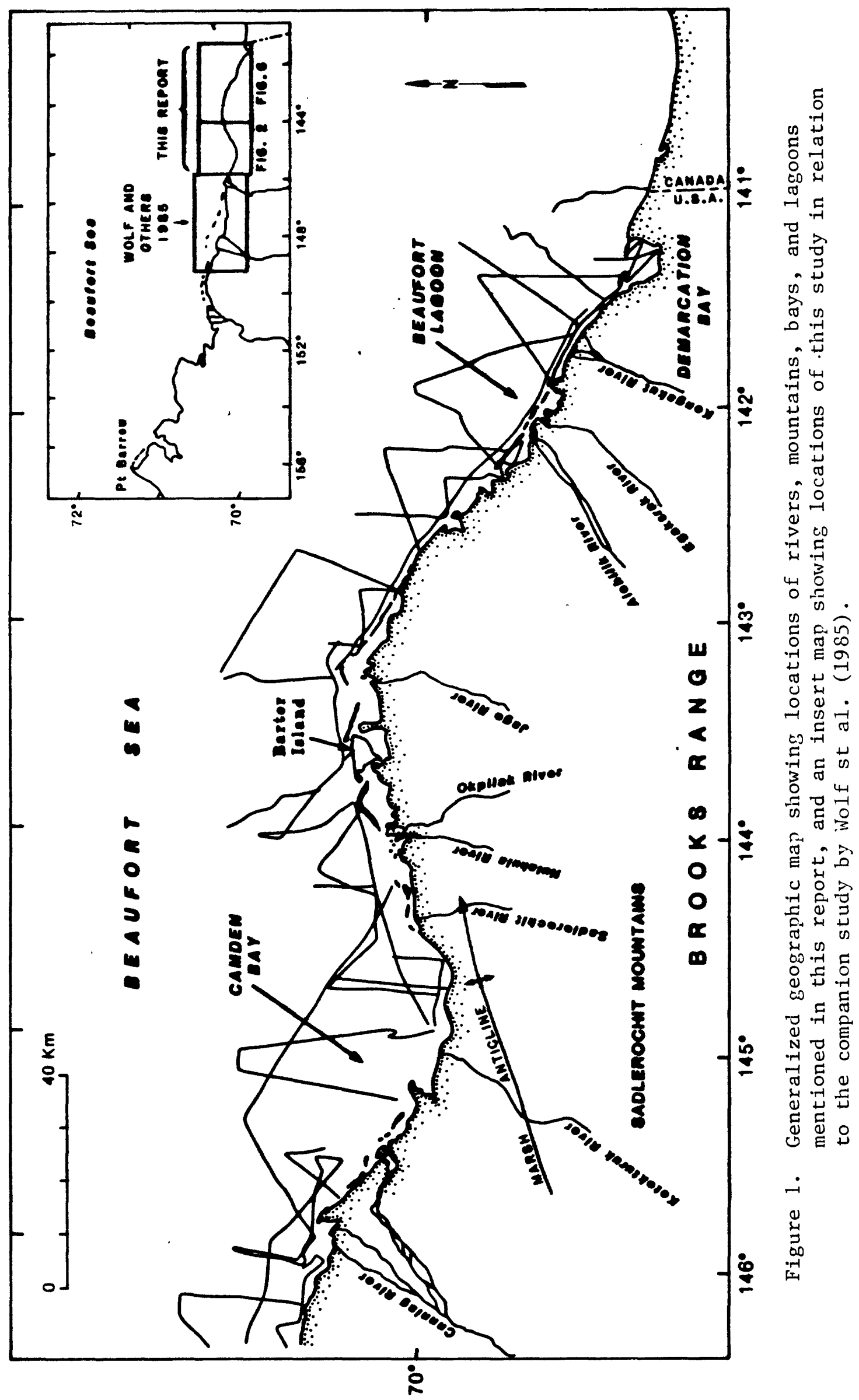


TABLE 1. R/V LOON and R/V KARLUK Log data for seismic track lines for the area from the Canning River to Demarcation Bay, Alaska (exclusive of side-scan sonar).

\begin{tabular}{|c|c|c|c|c|c|c|c|c|}
\hline Year & Date & Lin & e No. & $\begin{array}{c}\text { Julian } \\
\text { Date }\end{array}$ & $\begin{array}{c}\text { Time } \\
\text { Minisparker } \\
\end{array}$ & $\begin{array}{r}\text { Ro11 } \\
\text { No. } \\
\end{array}$ & Ro11 Time & $\begin{array}{r}\text { Rol1 } \\
\text { No. } \\
\end{array}$ \\
\hline 1972 & $\begin{array}{l}8 / 30 \\
8 / 30 \\
8 / 30 \\
8 / 30 \\
8 / 30 \\
8 / 30 \\
8 / 30\end{array}$ & $\begin{array}{l}\text { Line } \\
\text { Line } \\
\text { Line } \\
\text { Line } \\
\text { Line } \\
\text { Line } \\
\text { Line }\end{array}$ & $\begin{array}{r}5-71 \\
6-71 \\
7-71 \\
8-71 \\
9-71 \\
10-71 \\
11-71\end{array}$ & $\begin{array}{l}242 \\
242 \\
242 \\
242 \\
242 \\
242 \\
242\end{array}$ & $\begin{array}{l}1532-1611 \\
1615-1648 \\
1654-1726 \\
1756-1815 \\
1950-2018 \\
2021-2107 \\
2111-2155\end{array}$ & $\begin{array}{l}(5) \\
(6) \\
(7) \\
(8) \\
(8) \\
(10) \\
(11)\end{array}$ & $\begin{array}{l}\text { Barter Island } \\
\text { Survey }\end{array}$ & \\
\hline 1980 & $\begin{array}{l}7 / 19 \\
7 / 20 \\
7 / 21 \\
7 / 21 \\
7 / 22 \\
7 / 23\end{array}$ & $\begin{array}{l}\text { Line } \\
\text { Line } \\
\text { Line } \\
\text { Line } \\
\text { Line } \\
\text { Line }\end{array}$ & $\begin{array}{l}1-80 \\
2-80 \\
3-80 \\
4-80 \\
5-80 \\
6-80\end{array}$ & $\begin{array}{l}201 \\
202 \\
203 \\
203 \\
204 \\
205\end{array}$ & $\begin{array}{l}1305-1455 \\
0830-1048 \\
1151-1900 \\
0600-1630 \\
0900-1915\end{array}$ & $\begin{array}{l}(1) \\
(1) \\
(1-2) \\
(2) \\
(2-3)\end{array}$ & $\begin{array}{l}\text { Ro11 Time } \\
1245-1530 \\
1305-1455 \\
0830-1048 \\
1151-1900 \\
0600-1630 \\
0900-1915\end{array}$ & $\begin{array}{l}(1) \\
(1-2) \\
(2-3) \\
(3-4) \\
(4-5) \\
(6-7)\end{array}$ \\
\hline$\overline{1981}$ & $\begin{array}{l}7 / 20 \\
7 / 21 \\
7 / 22 \\
7 / 23 \\
7 / 24 \\
7 / 24 \\
7 / 25 \\
7 / 27 \\
8 / 9 \\
8 / 10 \\
8 / 11 \\
8 / 11 \\
8 / 12 \\
8 / 13 \\
8 / 14 \\
8 / 15\end{array}$ & $\begin{array}{l}\text { Line } \\
\text { Line } \\
\text { Line } \\
\text { Line } \\
\text { Line } \\
\text { Line } \\
\text { Line } \\
\text { Line } \\
\text { Line } \\
\text { Line } \\
\text { Line } \\
\text { Line } \\
\text { Line } \\
\text { Line } \\
\text { Line } \\
\text { Line }\end{array}$ & $\begin{array}{r}8-81 \\
9-81 \\
10-81 \\
11-81 \\
12-81 \\
13-81 \\
14-81 \\
15-81 \\
31-81 \\
32-81 \\
33-81 \\
34-81 \\
35-81 \\
36-81 \\
37-81 \\
38-81\end{array}$ & $\begin{array}{l}201 \\
202 \\
203 \\
204 \\
205 \\
205 \\
206 \\
209 \\
221 \\
222 \\
223 \\
223 \\
224 \\
225 \\
226 \\
227\end{array}$ & $\begin{array}{l}0849-1900 \\
0845-1356 \\
0952-1252 \\
1338-1825 \\
0939-1650 \\
0834-1125 \\
1735-1900 \\
1205-1947 \\
1041-1345 \\
1604-1902 \\
1110-1651 \\
0941-1714 \\
1124-1425 \\
0831-1152\end{array}$ & $\begin{array}{l}(1-2) \\
(2-3) \\
(3) \\
(3) \\
(4) \\
(4-5) \\
(6) \\
(6) \\
(7) \\
(7) \\
(8) \\
(8-9) \\
(9) \\
(10)\end{array}$ & $\begin{array}{l}0930-1400 \\
0849-1900 \\
0957-1725 \\
0845-1356 \\
0952-1252 \\
1338-1825 \\
0930-1650 \\
0834-1125 \\
1735-1900 \\
1205-1947 \\
1041-1345 \\
1604-1902 \\
1110-1651 \\
0941-1714 \\
1124-1425 \\
0831-1152\end{array}$ & $\begin{array}{l}(3) \\
(4-5) \\
(6-7) \\
(7-8) \\
(8) \\
(9) \\
(10-11) \\
(11) \\
(23) \\
(23-24 \\
(25) \\
(26) \\
(26-27) \\
(27-28) \\
(29) \\
(29)\end{array}$ \\
\hline 1982 & $\begin{array}{l}9 / 3 \\
9 / 5 \\
9 / 5\end{array}$ & $\begin{array}{l}\text { Line } \\
\text { Line } \\
\text { Line }\end{array}$ & $\begin{array}{r}8-82 \\
9-82 \\
10-82\end{array}$ & $\begin{array}{l}246 \\
248 \\
248\end{array}$ & $\begin{array}{l}1706-2020 \\
0850-1544 \\
1545-1855\end{array}$ & $\begin{array}{l}(2) \\
(2-3) \\
(3)\end{array}$ & & \\
\hline
\end{tabular}

\begin{tabular}{lllll}
\hline \multirow{4}{*}{1983} & & & & Geopulse \\
\cline { 3 - 5 } & $8 / 8$ & Line $26-83$ & 220 & $1450-1800$ \\
& $8 / 8$ & Line $27-83$ & 220 & $1800-2145$ \\
$8 / 9$ & Line $28-83$ & 221 & $1333-1725$ \\
& $8 / 9$ & Line $29-83$ & 221 & $1925-2000$ \\
$8 / 9$ & Line 30-83 & 221 &
\end{tabular}

Thermal Depth

Sounder

(4) $\quad 1420-1800$ (3)

(5) $\quad 1800-2145$

(3)

(5) 1333-1725

(3)

(6) 1925-2000

(4)

2032-2l10

(4) 


\section{PHYSIOGRAPHY}

\section{Onshore Coastal Plain Physiography}

A brief description of the coastal plain physiography is given to provide an insight into the type of terrane encountered by the transgressing sea during the post glacial rise in sea level. A more detailed physiographic description of the entire area may be found in Walker et al. (1982). The western portion of the coastal plain in this study extends from the Canning River to Barter Island and encompasses Camden Bay. The hills in this area are bigger than those on the coastal plain to the east. Because the land rises steeply from the sea, coastal bluffs up to $10 \mathrm{~m}$ in relief can be observed. Stream drainage is well defined across the irregular surface which is characterized by thaw lakes and ponds. The Canning, Katakturuk, Sadlerochit, Hulahula and Jago Rivers flow into Canden bay. Except for the Jago River, each river has a delta at the coast line; the largest is associated with the Canning River. The hilly coastal plain rises southward from Camden Bay to the Sadlerochit Mountains over a distance of 40-50 kilometers (fig. 1).

The irregular coastline east of Barter Island consists of many lagoons and bays, but is dominated by barrier islands. The coastline is backed by low-lying tundra with small bluffs reaching heights of about $8 \mathrm{~m}$ near Barter Island. The coastal onshore area east of Barter Island is characterized by gentle slopes ascending from the coast toward the foothills of the Brooks Range some 25-50 kilometers to the south. Numerous lakes are interspersed within the hilly terrain. Active and abandoned stream channels have resulted in the formation of a dissected land surface. The largest rivers flowing to the Beaufort Sea in this area are the Aichilik, Egaksrak, and Kongakut, which have small deltas at their mouths (fig. 1).

The eastern portion of the coastal plain is characterized by two large fans to the south and west of Demarcation Bay (fig. 14). The Brooks Range lies only 20 kilometers south of the coastline and, as a consequence, the fans have steep gradients. The largest fan, formed by the Kongakut River, terminates at the coast leading to the formation of barrier islands, narrow lagoons, and minor deltas. The smaller fan to the east is somewhat irregular in shape, being cut by Demarcation Bay on the west and having a coastal plain lake morphology in the central sector.

\section{Offshore Physiography}

The inner shelf of the Beaufort Sea has a gentle seaward gradient with bathymetric contours which generally are subparallel to the coastline. In Camden Bay, water depths of $40 \mathrm{~m}$ are north of the coastline; a distance of about 40 kilometers (fig. 2). From Barter Island eastward, the seafloor gradient is twice as steep as west of Barter Island where depths reach $40 \mathrm{~m}$ within about 20 kilometers from the coast (fig. 6). Side-scan sonar data show the seafloor to be severely ice-gouged throughout the region (Reimnitz and others, 1982). A large offshore ridge with relief of 4-8 $\mathrm{m}$ and length of approximately $30 \mathrm{~km}$ trends semi-parallel to the coastline from Barter Island southeastward at a distance of 10-12 kilometers offshore. This ridge is commonly congested with grounded ice masses, which impedes deep draft ice from flowing onshore (Reimnitz and others, 1978). Seismic reflector data indicate the ridge is an erosional remnant related to underlying geology. Similar ridges or shoals were observed in Camden Bay and are related to both the underlying geology and to constructional processes. These ridges will be discussed in more detail later in the report. 


\section{SEISMIC DATA AND ANALYSES}

All seismic data along the tracklines shown in Figures 2 and 6 were interpreted in order to determine reflectors which might be correlated throughout the area. Only two acoustic surfaces, which we have called horizons $A-A^{\prime}$ and $B$, were found to be traceable over most of the study area. The shallower surface, horizon $B$, was found to be less continuous than horizon A-A', particularly in Camden Bay; as such it could not be contoured with any confidence. However, its relationship in depth below sea floor and vertical separation from horizon A was fairly consistent where observed. Nevertheless, sufficiently large areas or gaps existed in the acoustic data for horizon B to make correlation of the horizon from line to line difficult. These gaps are principally a result of wide line spacing, poor resolution, and/or diminished acoustic impedance resulting from the presence of identical acoustic facies above and below the horizon.

In Camden Bay west of Barter Island, the stratigraphy is complicated by the presence of complex subsurface structures which will be discussed later. The stratigraphy east of Barter Island is simple, showing units which are conformable to each other. In the eastern area, however, acoustic units above and below horizons $A$ and $B$ in places show cut and fill channels which are traceable over short distances only due to wide spacing of track lines. The complex subsurface structures effectively divide each horizon surface into two sections. For the purpose of the following discussion, horizon A' will refer to the Camden Bay section and horizon A for the section between Barter Island and Demarcation Bay. Horizon B, for reasons stated above, will not be subdivided. Although surfaces $A$ and A' may in fact be equivalent to each other in time of formation and proximity to the coastline, there is a lack of sufficient seismic data to confirm this hypothesis.

Two reflectors, which lie above horizons A, A', and B throughout the area are actively being destroyed by intense ice gouging, particularly along the seaward margin of the area. These young reflectors have seaward dips along the inner shelf, flatten seaward, and are being truncated at the seafloor over much of the region.

The uppermost acoustic sedimentary sequence, which consists of an acoustically transparent unit, was found in four places in the study area; in Camden Bay, in the central outer portion of the study area north of Beaufort Lagoon, in Beaufort Lagoon, and within Demarcation Bay. Very high resolution $(7 \mathrm{kHz})$ data were useful in resolving sediments near the seafloor which were a meter or more in thickness.

\section{DESCRIPTION AND SIGNIFICANCE OF ACOUSTIC REFLECTORS}

\section{Canning River to Barter Island}

Tracklines interpreted in this area are concentrated into two groups with little coverage between; this made correlation from one group to the other difficult. One trackline set is in Camden Bay centered around line 6-80; the other is north-northwest of Barter Island centered around line 4-80 (fig. 2).

The Camden Bay and Barter Island sets of tracklines exhibit different structures and seismic stratigraphies. The Camden Bay sequence is similar to that described for the region between Barter Island and Demarcation Bay but horizon $A^{\prime}$ has more relief than horizon $A$. 


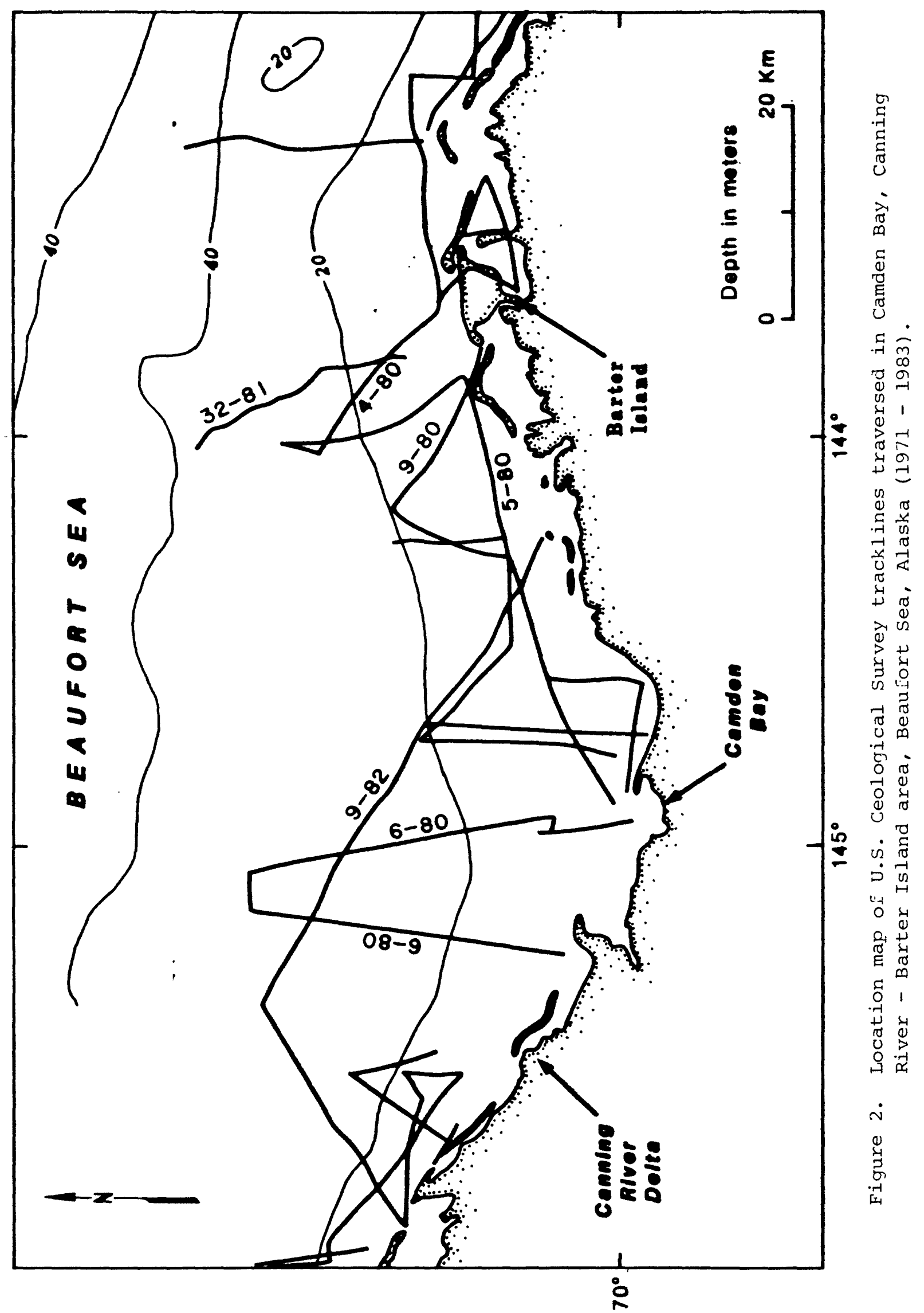


Data gaps and complex structural trends near Barter Island prevent the tracing of features from the Canning River to parts east of Barter Island. Therefore, the stratigraphic sequences of the Camden Bay and Barter Island trackline sets are considered separately.

The Camden Bay set lies adjacent to the area that was studied in detail and was described by Wolf and others (1985). The report concluded that a broad subsurface delta system, which overlies relatively flat lying marine sediments, exists immediately west of the present study area.

\section{Camden Bay Area}

The seafloor in Camden Bay is depicted in Figure 3. Of significant physiographic interest are the long linear ridges which are apparently subparallel to the bathymetric contours. These ridges have no internal reflectors in some cases, but generally are residual highs composed of eroded, relatively flat-lying sedimentary sequences, much like those north of Barter Island. Ridge $A$, the long 2-meter ridge of Figure 3 appears to be constructional as it lacks internal reflectors and is situated shoreward of a subsurface structural high. Likewise ridge B, a one meter ridge to the south also lacks internal reflectors but has sedimentary sequences lapping onto its north and south flanks (fig. 3). This configuration suggests that this particular ridge may be a submerged barrier island formed at a lower stand of sea level.

The seaward-dipping seismic unit 3 and the relatively flat-lying units 2 and 1 nearer the shoreline are remarkably similar to nearshore acoustic units east of Barter Island. Until further seismic data are acquired, one can assume, on the basis of similar acoustic signatures and distribution, that these units are the same as those described between Barter Island and Demarcation Bay.

An area of acoustically transparent sediment was observed south of ridge A of Figure 3. The accumulation is up to 4 meters thick and may represent an area of "Holocene" deposition. Sediment samples and additional seismic-reflection data are needed to substantiate this hypothesis.

The east and south dips of unit 3 shown in the extreme northern portion of the area suggest a subsurface high. This high may represent a near surface reflection of the deeper Camden Anticline (Grantz and others, 1983b). Unit 2 to the south rises to the north and crops out both there and on its south flank (see fig. 4). The seafloor has a slight northward gradient and is intensely ice gouged.

Except for the area of possible "Holocene" sediment accumulation and constructional ridges, the entire area, like the region to the east of Barter Island, is undergoing intense ice gouging; the area appears to be a region of little deposition and probably is an area of erosion.

The contoured surface of horizon $A^{\prime}$ (fig. 4) shows variable relief unlike surface A between Barter Island and Demarcation Bay. Seismic data show reflectors which top lap into the surface and indicate that this surface is an unconformity. The relief, therefore, may reflect directions of surface drainage during the time the erosional surface was formed. The underlying anticlinal high, at depth, to the north of the area may have played a dominant role in controlling relief. Drainage from an ancestral Camden Bay may have been disrupted by a growing Camden anticline and been forced to flow to the northeast and northwest around the high. The 


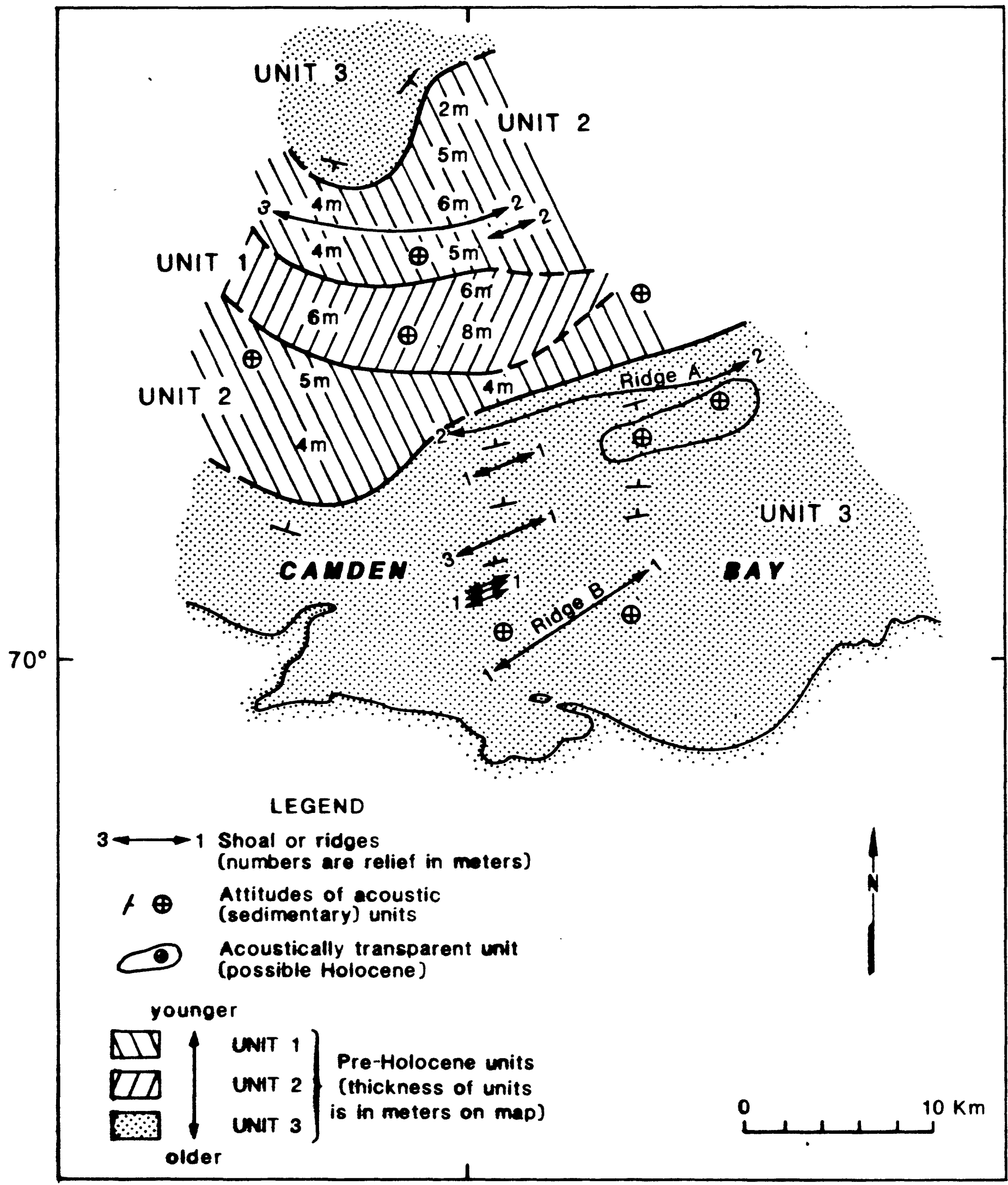

\section{$145^{\circ}$}

Figure 3. Sea floor map showing apparent distribution and attitudes of eacin geologic unit in Camden Bay. 


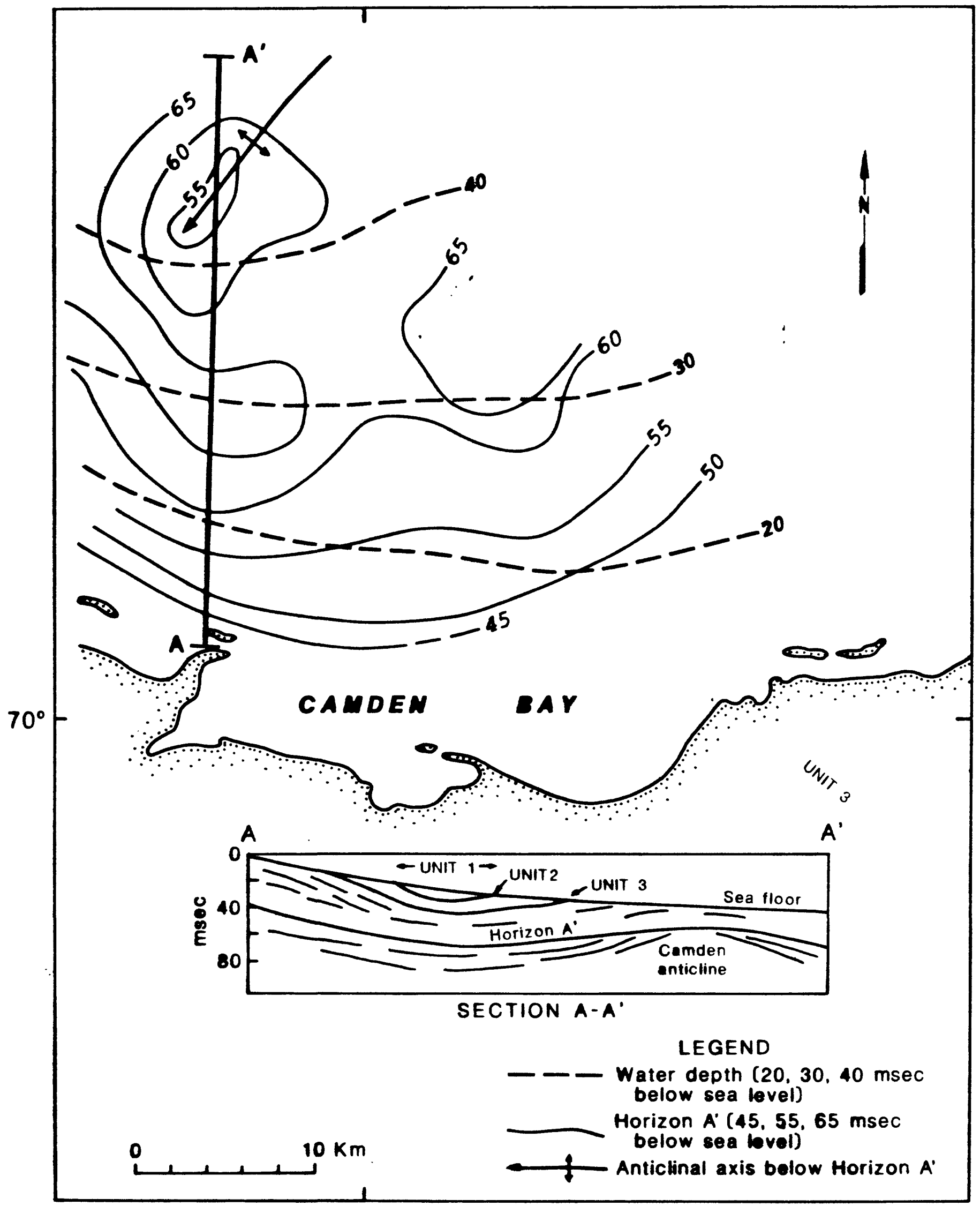

$145^{\circ}$

Figure 4. Contour map drawn on surface of Horizon A' 
acoustic stratigraphy above and below horizon $A^{\prime}$ shows a significant number of cut and fill channels, suggesting that this region has had an active depositional and erosional history. The equivalent of horizon B was more difficult to resolve in this area than in the region east of Barter Island perhaps as a result of this increase in a depositional and erosional activity and the topographic influence of the growing anticlinal high on accumulation and removal of sediments. The sequences that top lap into horizon $A^{\prime}$ and define the near surface expression of the anticlinal high suggest that sedimentation rates are less since the formation of horizon $A^{\prime}$ than occurred before the events that formed horizon A'; however, periods of cutting and filling of channels continued to occur and indicate a history that is similar to the one suggested for the area from Barter Island to Demarcation Bay.

\section{Barter Island Area}

Figure 5 is a subsurface map of a sedimentary structure centered approximately 20 kilometers north of Barter Island. The structure consists of a folded and faulted sequence containing two geologic units (4 and 5) with differing apparent dips. On seismic records, the angular terminations of beds at this contact suggest that there is an unconformity between the two stratigraphic units. The unit northwest of the contact is anticlinal with evidence of faulting along the south flank. The unit southeast of the contact appears to lap onto this large structure and is characterized by very slight dips to the southeast.

Outcrops of both stratigraphic units may be present on the seafloor but seismic and $7 \mathrm{kHz}$ records do not allow their delineation. The presence of this subsurface structure demands that horizon $A$, to the east, and $A^{\prime}$ to the west, must crop out on the seafloor along the flanks of the structure, thus suggesting that these two different stratigraphic units (4 and 5) are much older than horizons $\mathbf{A}$ and $\mathbf{A}^{\prime}$. Additional seismic data will be required to delineate and tie these stratigraphic units together with horizons $A$ and $A^{\prime}$.

A sediment cover of variable thickness overlies this structure. As much as 4-m of sediment cover occurs above the structure in the southeast portion of the area. Bedding features within this sediment cover are being destroyed by ice gouging. This cover thins near the anticlinal axis.

The series of faults and dips northwest of Barter Island and in the lagoons to the south (fig. 5) align rather well with the northeasterly trend of the Marsh anticline which lies well to the southwest. Bedrock in the lagoons is close to the lagoon floors and covered by thin Holocene(?) deposits.

\section{Barter Island to Demarcation Bay}

\section{Horizons $A$ and $B$}

Figure 6 is a map showing USGS trackline coverage which provided seismic data to delineate horizons A and B throughout much of the area. Our data extend to water depths of 40 $\mathrm{m}$ and achieve as much as $50 \mathrm{~m}$ subbottom penetration. Figure 7 is a representative seismic reflection profile showing acoustic stratigraphy on the inner shelf between Barter Island and Demarcation Bay. 


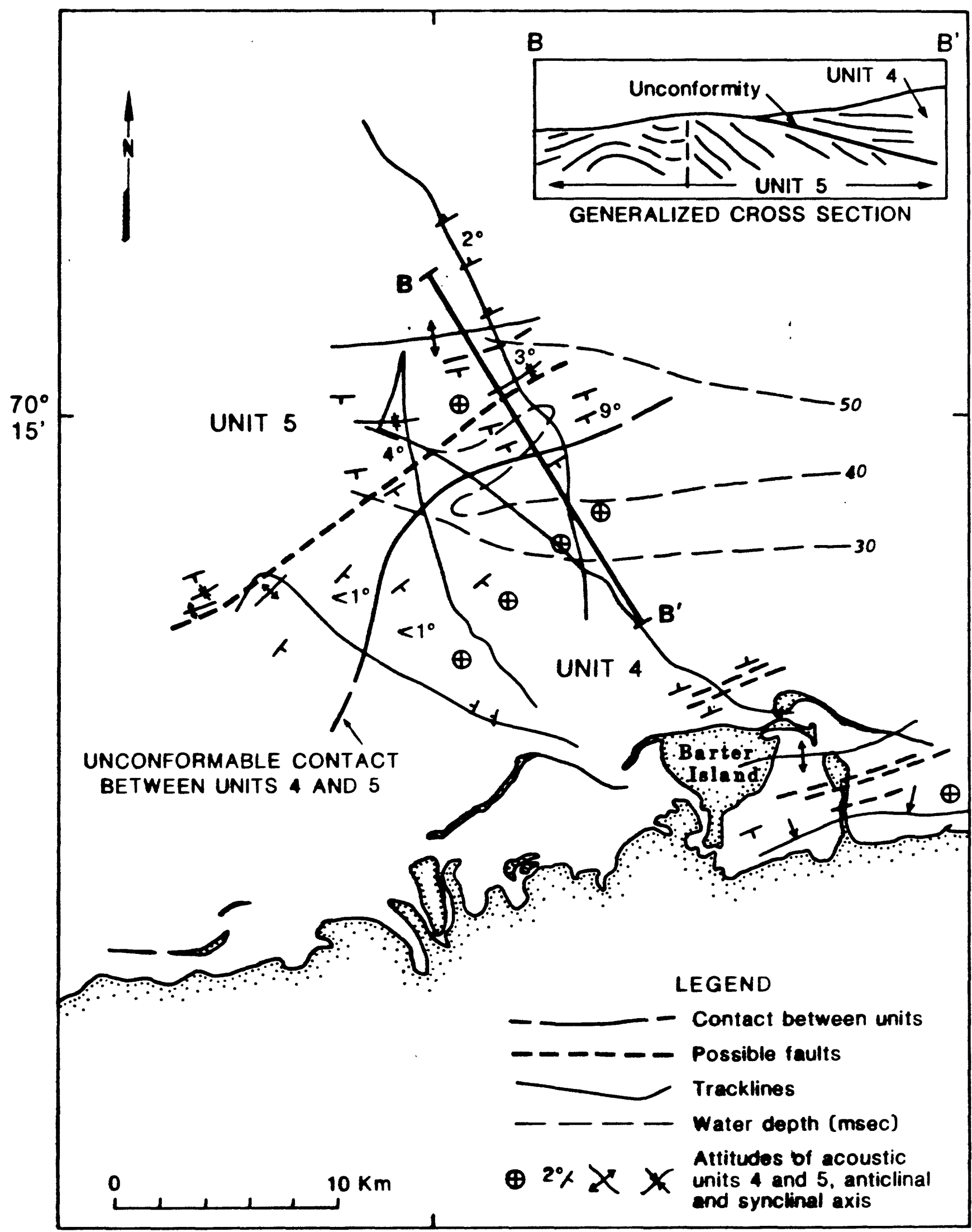

$144^{\circ} 00^{\prime}$

Figure 5. Map showing subsurface structures northwest of Barter Island. 


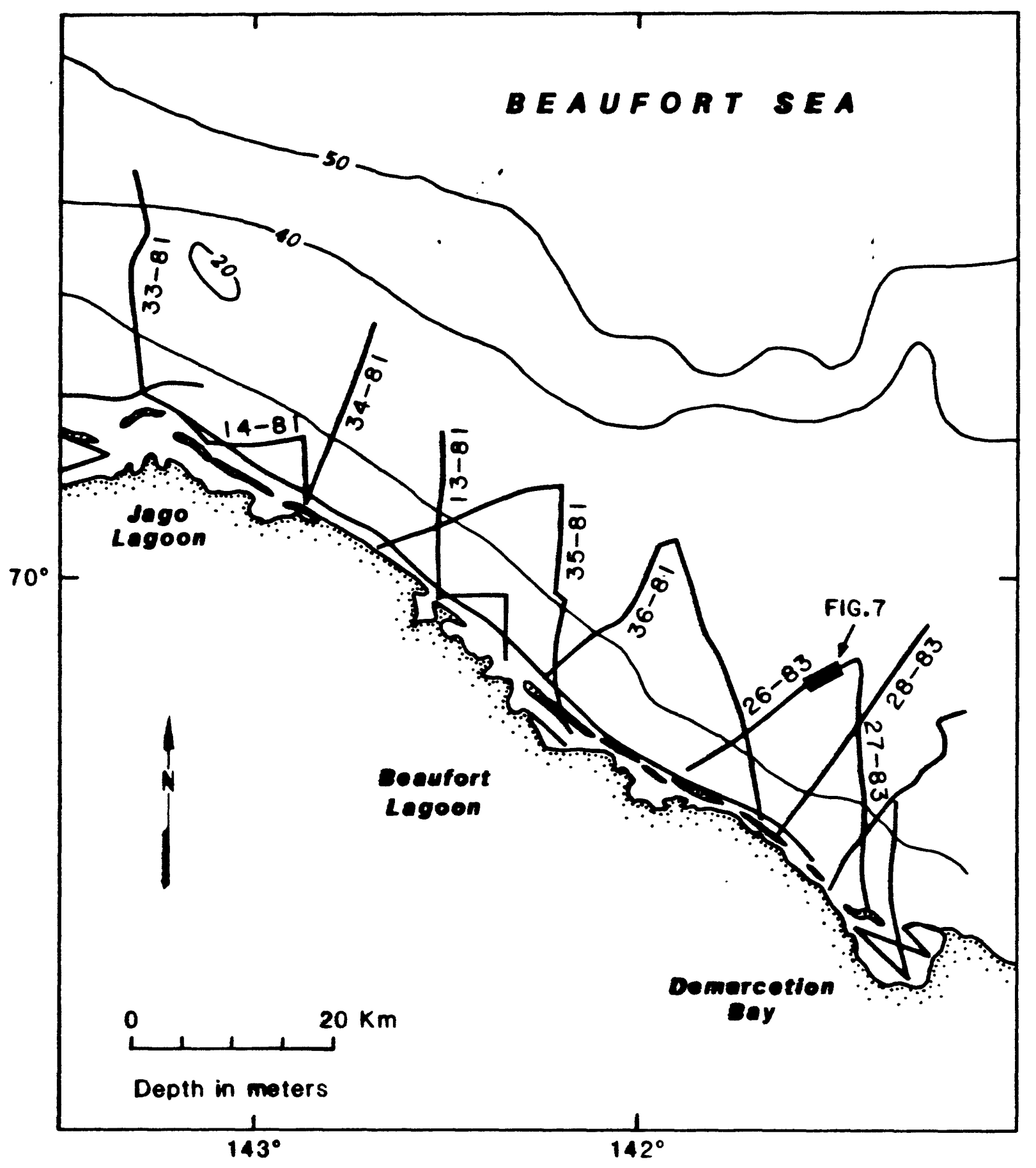

Figure 6. Location map of U.S. Geological Survey tracklines traversea in the Barter Island - Demarcation Bay Area, Beaufort Sea, Alaska, during tile period 1971 - 1933. 


\section{Horizon A}

The most persistent and deepest reflector is horizon A (fig. 7). Below horizon A throughout much of the area, the acoustic signal is weak and little bedding is observable. Seaward (northward) dipping reflectors can be seen top lapping into horizon A on line 34 (fig. 8). Similar features observed along other seismic lines suggest that horizon A represents an unconformity. Based on interpretations at many onshore-offshore trackline crossings, it appears that horizon $A$ is approximately $45-50$ meters below the seafloor (BSF) in water depths of $40 \mathrm{~m}$ along the outer limits of the area surveyed. Horizon A shallows to approximately 30 meters BSF in the mid-region at approximately $25 \mathrm{~m}$ water depth. Seismic data are marginal near the cost making it difficult to delineate horizon $\mathrm{A}$.

\section{Horizon B}

The next higher major acoustic boundary, horizon B, was somewhat difficult to resolve as a continuous linear refiector. In general, however, it is seen as the top of an acoustic sequence composed of closely spaced, thinly laminated, coherent reflectors (fig. 7). These reflectors are relatively flat lying with local areas of seaward dipping internal reflectors. Above horizon $A$ but below horizon B is a unit characterized by widespread but persistent reflectors in a rather homogeneous sequence (fig 8, upper profile).

Horizon B in Figure 9 (upper profile), as with horizon A in Figure 8, indicates that units below are top lapping into the horizon surface. This evidence suggests that horizon $B$ also may be an unconformity. There are numerous examples that support this interpretation. In Figure 9 (upper profile), horizon A has only subtle suggestions of top lapping units. In Figure 9 (lower profile), horizon $\mathrm{A}$ is obscured by locally strong multiples. Horizon $\mathrm{B}$, on the other hand, although occasionally blocked by what appears to be gas, has a very high acoustic impedance. This high reflectivity occurs in many areas especially near the coastline. In general, horizon B lies approximately 15 meters BSF in $40 \mathrm{~m}$ water depth and shallows to 5 meters BSF in $15 \mathrm{~m}$ water depth. Seismic data near the coast are marginal, but it appears that horizon B may crop out near the coastline.

Generally, horizons A and B lie subparallel to the seafloor, with most cut-and-fill channels occurring between the two. The largest channel observed lies below horizon $B$ with the base defined by horizon $A$; the channel is situated approximately 10 kilometers north of Demarcation Bay and was observed on lines 26 to 28 of the 1983 cruise. The channel axis trends west-northwest to east-southeast, is approximately 10-12 kilometers in width and has 510 meters of relief. Its relationship to present land features is unclear, as line spacing does not allow us to extend the axis to the east or west.

\section{Units above Horizon B}

Above horizon B and commonly 5-10 meters below the seafloor in the outer part of the study area, is a third rather dominant horizon with an irregular surface which occasionally is composed of short overlapping horizontal 'mini' reflectors. Near the seafloor between times 1620 and 1630 (fig. 8, upper profile) 4 meters to 10 meters below the sea floor, lies an acoustic grouping of tightly spaced flat-lying reflectors. This grouping phenomenon and the irregular surface previously mentioned have been observed along other lines but not frequently enough to demonstrate continuity of either. The occasional grouping of reflectors may reflect a 


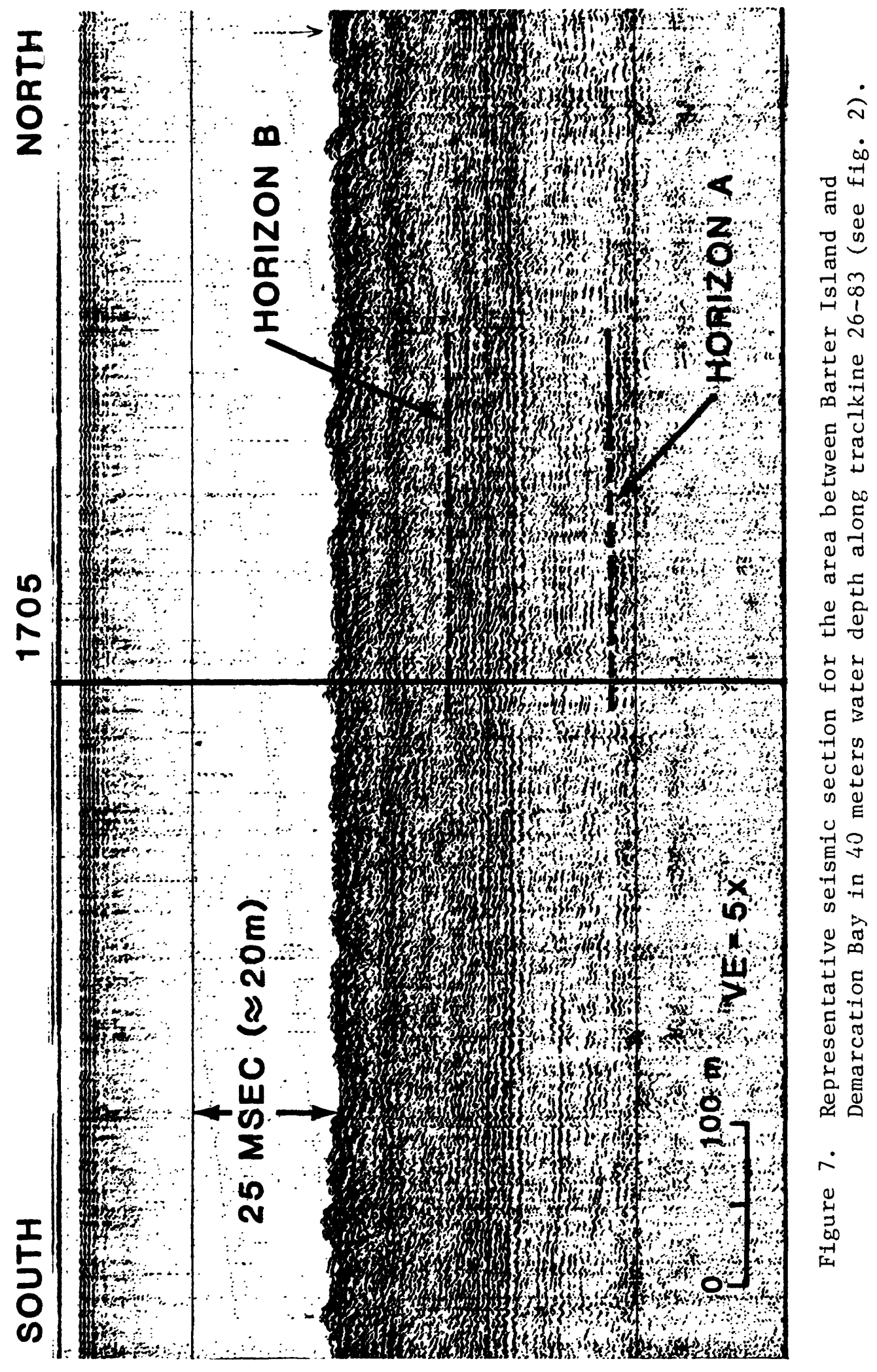




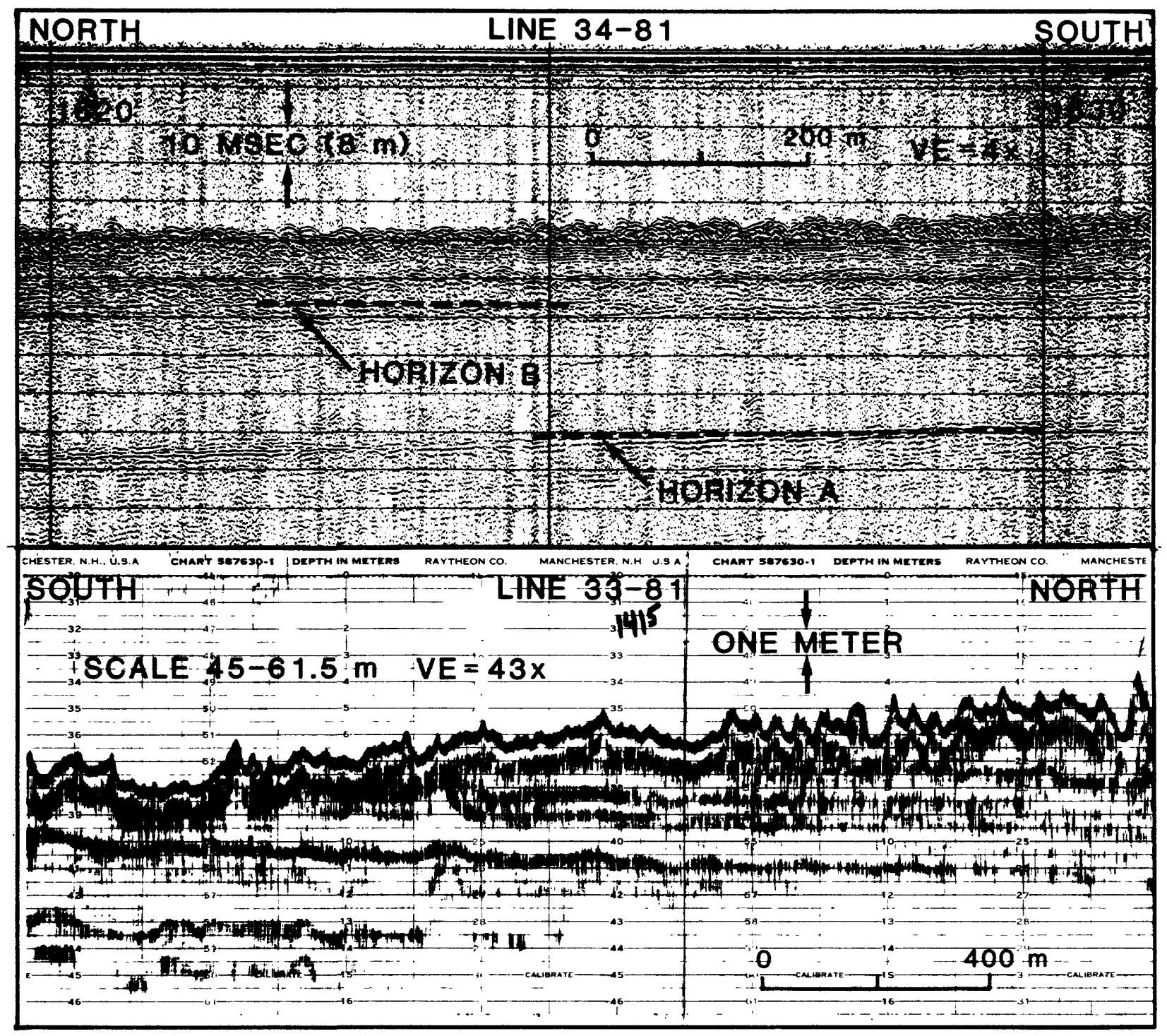

Figure 8. Uniboom data (line 34-81) and $7 \mathrm{kHz}$ data (line 33-81) north of Barter Island, Beaufort Sea, Alaska 

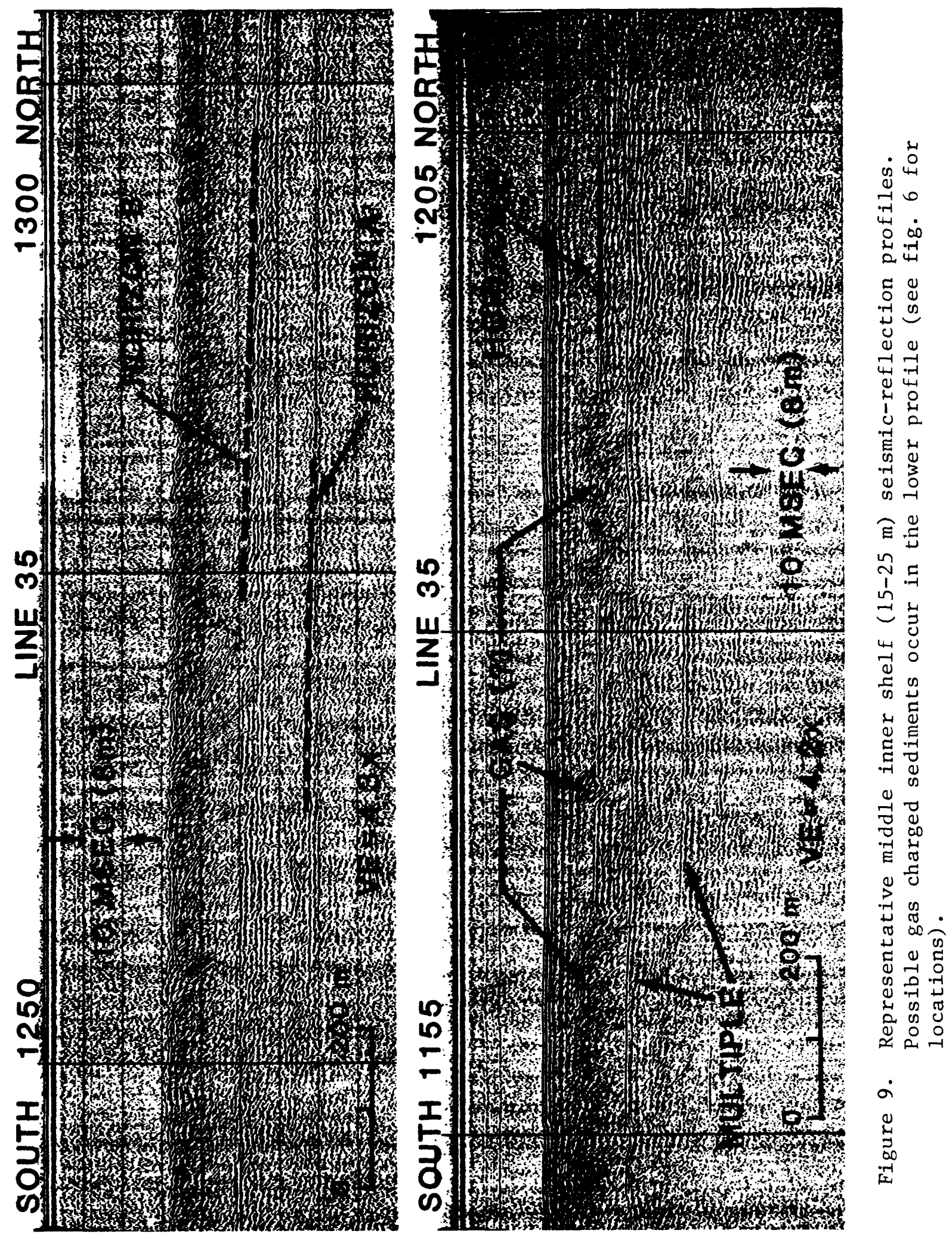
change in sediment type from nonbedded to bedded sequences which lie just below the seafloor in isolated areas.

The $7 \mathrm{kHz}$ record in the lower part of Figure 8 shows that these bedded units have not been deposited recently but rather are older units which are actively undergoing destruction by intense ice gouging, particularly north of Barter Island and where the gouging penetrates a meter or two down into the seafloor. Ice is acting as a nature made "rototiller" destroying previous stratigraphy and homogenizing the upper few meters of the seafloor sediments.

The effects of this scouring can also be demonstrated in the vicinity of the offshore shoals. The topographic high at the north end of Figure 8 (lower profile) is the inshore flank of a linear shoal north of Barter Island in approximately $50 \mathrm{~m}$ of water and trending to the southeast. During some surveys, this area was congested with large grounded ice masses. Acoustic reflectors within the shoal terminate at or near the seafloor and in this particular example, at least four meters of bedded materials to the south have been destroyed and removed from the area. This destruction by ice masses is characteristic throughout the area but is best shown along this shoal. Clearly, recent deposition is not occurring, but rather rapid degradation of the inner shelf and removal of sediments from the area is demonstrated. Excessive removal of sediments from the area may also have been facilitated by stream erosion during periods of low sea level stands.

Along the inner shelf, there are groups of reflectors which have seaward dips and appear to crop out at the seafloor. Figure 10 shows two examples of $7 \mathrm{kHz}$ records illustrating these seaward dipping reflectors. Dips along the tracklines are approximately 30 minutes although dips vary, suggesting a somewhat variable depositional history. Pinch outs of north-dipping wedges can be observed in the lower profile of Figure 10, especially toward the south end. These records are representative of others throughout the area. In most all cases, the reflectors appear to be truncated at or near the seafioor with little suggestion of Holocene sediment cover.

Figure 11 shows the distribution of the reflectors above horizon B. Geologic units, as defined by these reflectors, are generally horizontal along the coastline. These reflectors grade into the NW-SE trending belt of seaward dipping reflectors (unit 3) similar to those shown in Figure 10. Locally the uppermost reflectors, which defines the base of unit 2, flattens out seaward, is essentially parallel to the sea surface, and ranges from 0 to 8 meters in thickness. As a result of the seafloor having a seaward gradient greater than that of of this unit, the basal reflector should crop out farther seaward in some places. In fact, this does occur in the northwestern part of the area. The unit is actively being destroyed by ice gouging as shown in Figure 8. The presence of the offshore linear shoal north of Barter Island accounts for the preservation of the top reflector between the two areas of destruction. Another area of destruction occurs north of Demarcation Bay.

Above these reflectors and within the horizon disturbed by ice gouging, short discontinuous reflectors that are subparallel to the seafloor occur at relatively consistent depths. Throughout the area these short reflectors were observed near the seafloor, but a continuous surface as such was not noted. These short reflectors may be an acoustic impedance difference being established within the near-surface sediment as a result of ice keels that penetrated and slid along the subseafloor. It is possible that if conditions of sea level and ice availability remain static over long periods of time, a continuous subsurface reflector may be created by this process. Canadian researchers refer to the area above this reflector as the scour saturation 


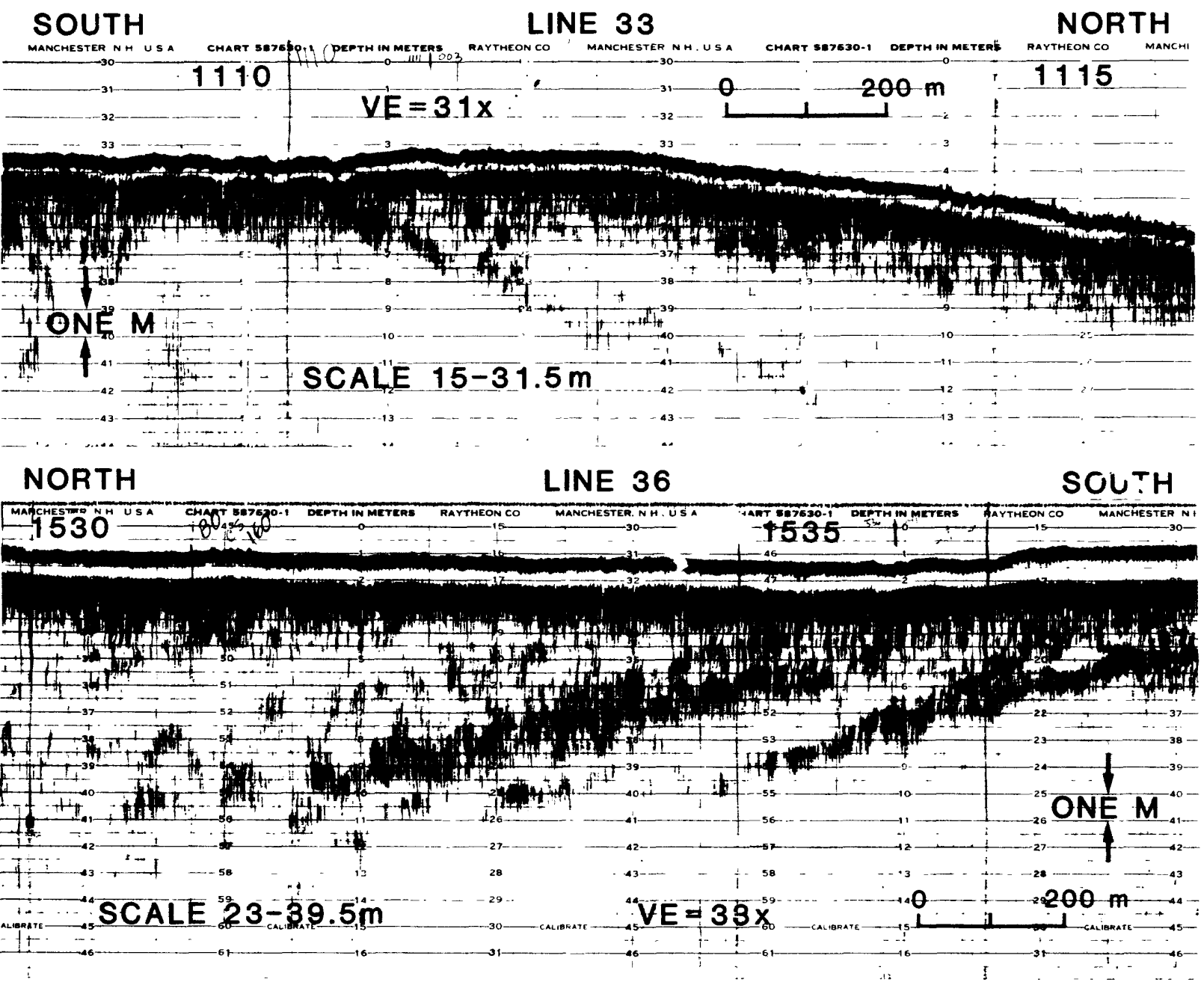

Figure 10. Examples of $7 \mathrm{kHz}$ records showing seaward-dipping reflectors that are truncated at the sea floor. 


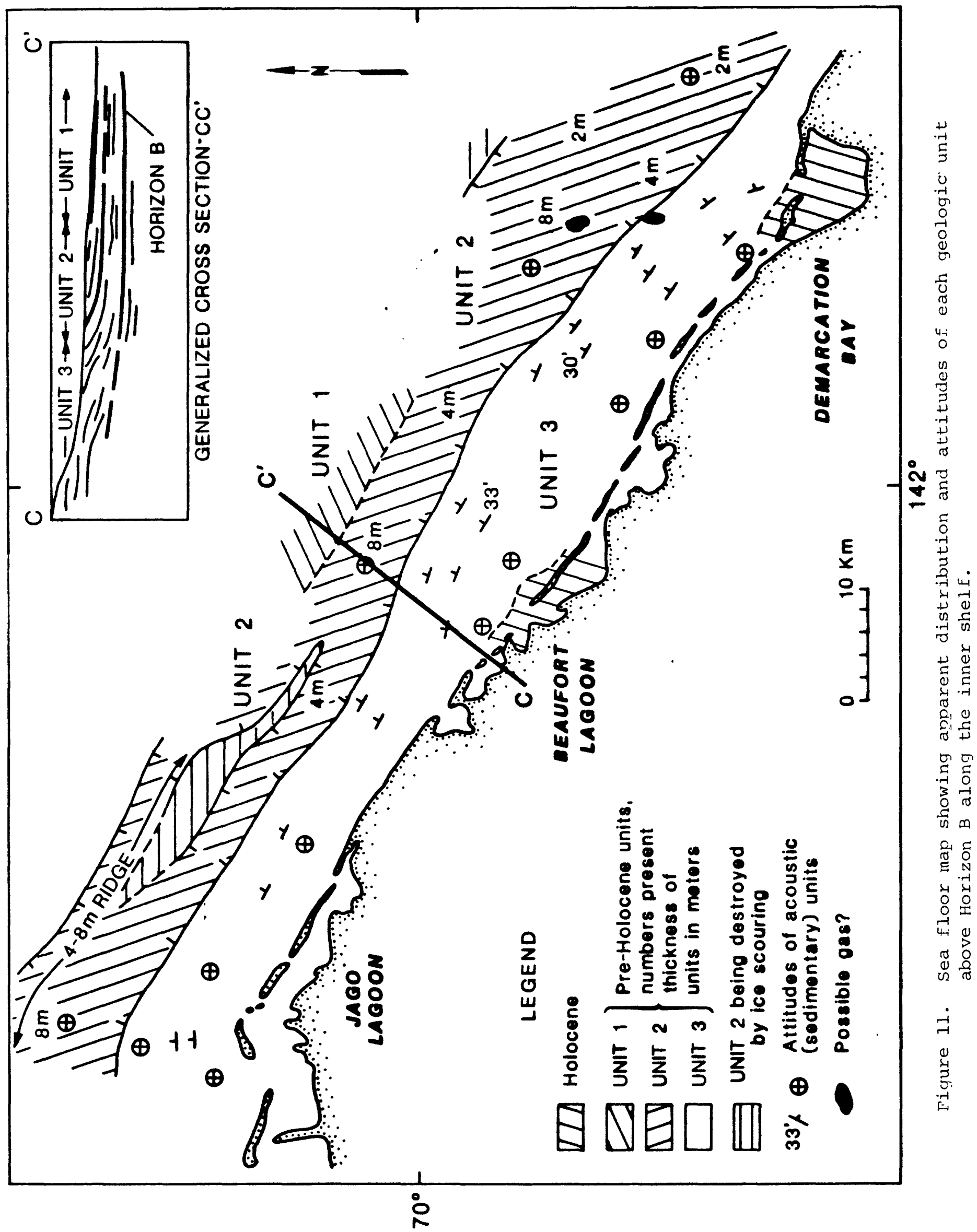


zone (SSZ) (M. O'Connor, Personal commun., 1982).

Youngest Units including Holocene

In the middle part of the area, north of Beaufort Lagoon (figs. 6 and 11), the "topflattening seaward" unit (unit 2) appears to be overlain by as an even younger unit. This youngest unit (unit 1) is shown on seismic sections in Figure 12. In both sections, the unit occurs in about $40 \mathrm{~m}$ of water and appears as a homogeneous, acoustically transparent sequence. In Figure 12 (lower section), the unit is very thin but increases to approximately 5meters thickness on line 35 (fig. 12, upper seçtion). At least two possible interpretations can be applied to this new unit. Either it is, in fact, a younger Holocene(?) accumulation, or it may represent a facies within the "top-flattening-seaward" unit described earlier. Line spacing does not permit extension of this unit to the northwest or southeast. The fact that the landward edge of this unit (unit 1) appears to be farther inshore than the boundary where ice gouging has destroyed unit 2 below, suggests that this "accumulation" may in fact be a sedimentary facies rather than Holocene sediment. On the other hand, the bathymetric contours which generally maintain a subparallel trend to the coastline suggest a slight depression or embayment in this area which might allow Holocene sediment to accumulate (see fig. 6). In general, if inner shelf accumulations of Holocene material are to be found, this area would be the most likely.

Holocene sediment is thought by many researchers to be present along barrier islands and in some bays and lagoons. Figure 13 shows unconsolidated Holocene(?) sediments as thick as 4 meters in Demarcation Bay. These sediments have been deposited on a surface of hummocky relief rather than on a flat or in a bowl-like feature. More than 3 to 4 meters of sediment has accumulated inshore of the spits and islands marking the seaward boundary of the bay particularly along the sand-gravel spit on the northwest side of the bay (fig. 13). Outside the bay, the thickness of Holocene(?) sediment thins to zero within one or two kilometers of the opening. Farther seaward, $7 \mathrm{kHz}$ records suggest the truncation of sedimentary units at the sea floor as discussed earlier. The zero contour marks the transition zone between present day nearshore deposition and offshore erosion or lack of deposition.

LANDSAT imagery (fig. 14) suggests areas of active Holocene deposition at the terminus of the large fan along the coast west of Demarcation Bay. The light gray areas in the water indicate turbid water masses trapped behind the barrier islands and partly within Demarcation Bay. False-color imagery shows minor sediment laden water masses exiting through passes between barrier islands into the Beaufort Sea. Flow of water masses was eastward at the time this image was acquired.

Beaufort Lagoon, midway between Barter Island and Demarcation Bay, is another area that appears to have a similar thickness of Holocene(?) sediment (fig. 11). In Figure 15, the thickest deposits include the barrier islands within the contour lines. This suggests, as one might expect, that the barrier islands in this region are Holocene and that some Holocene sediment has accumulated subparallel to the islands on both the seaward and lagoonal sides. The transition to an erosional surface again occurs a few kilometers offshore from the barrier islands, similar to the distribution of Holocene(?) sediment in Demarcation Bay. Coincidently, both areas reflect Holocene sediment accumulations of approximately 3-4 meters. 

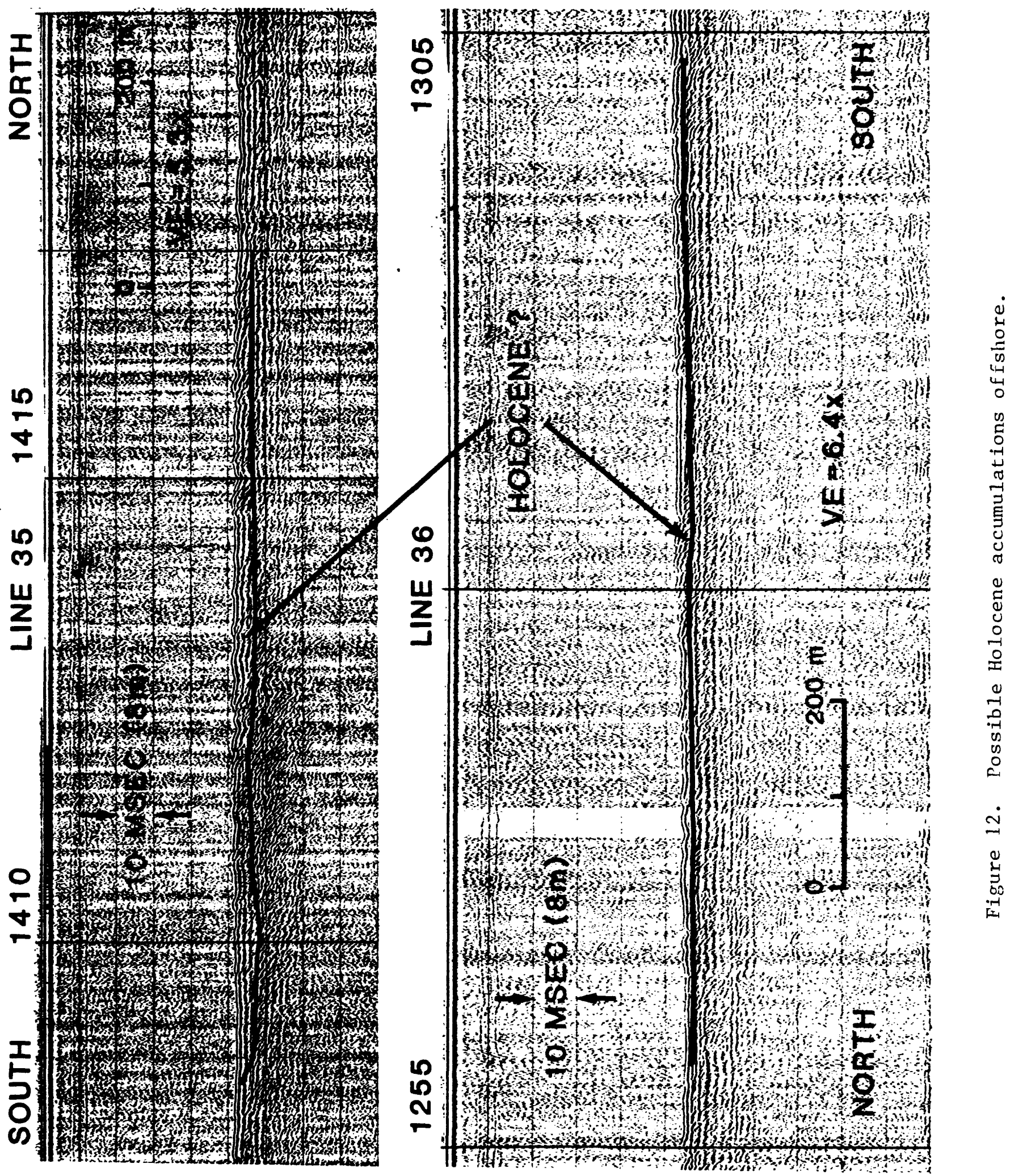


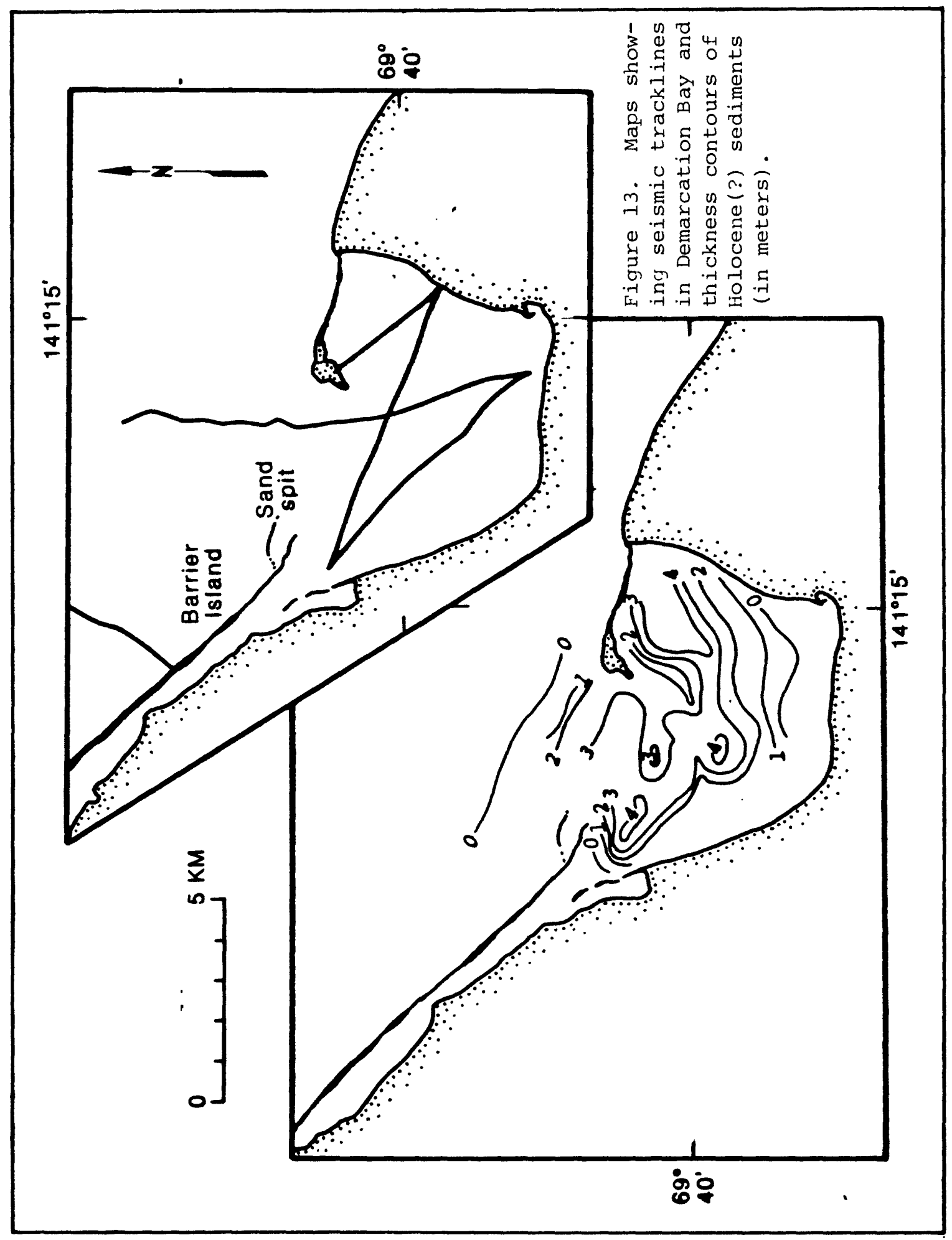




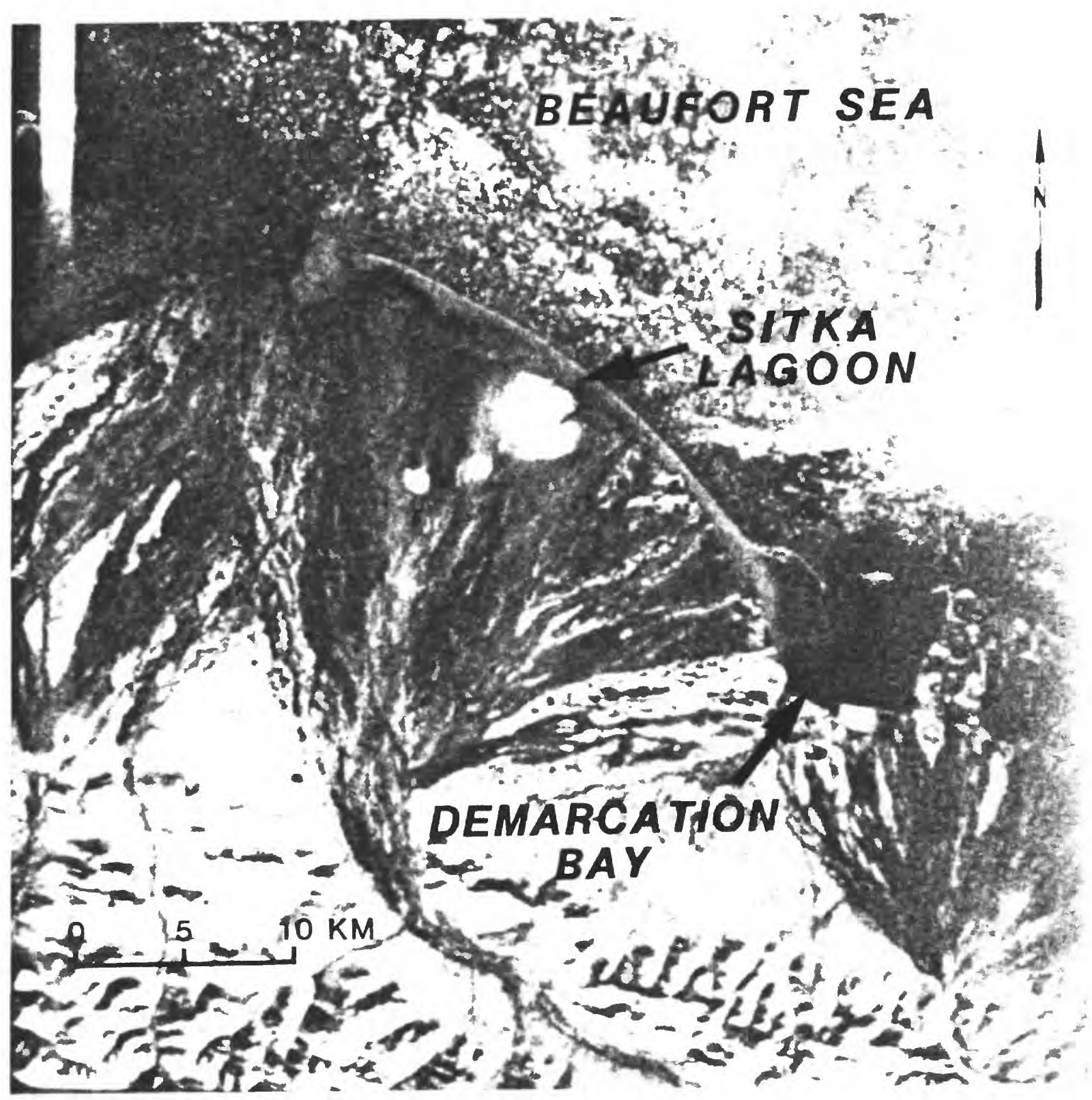

Figure 14. LANDSAT imagery of Demarcation Bay, adjacent fans, and barrier islands. 


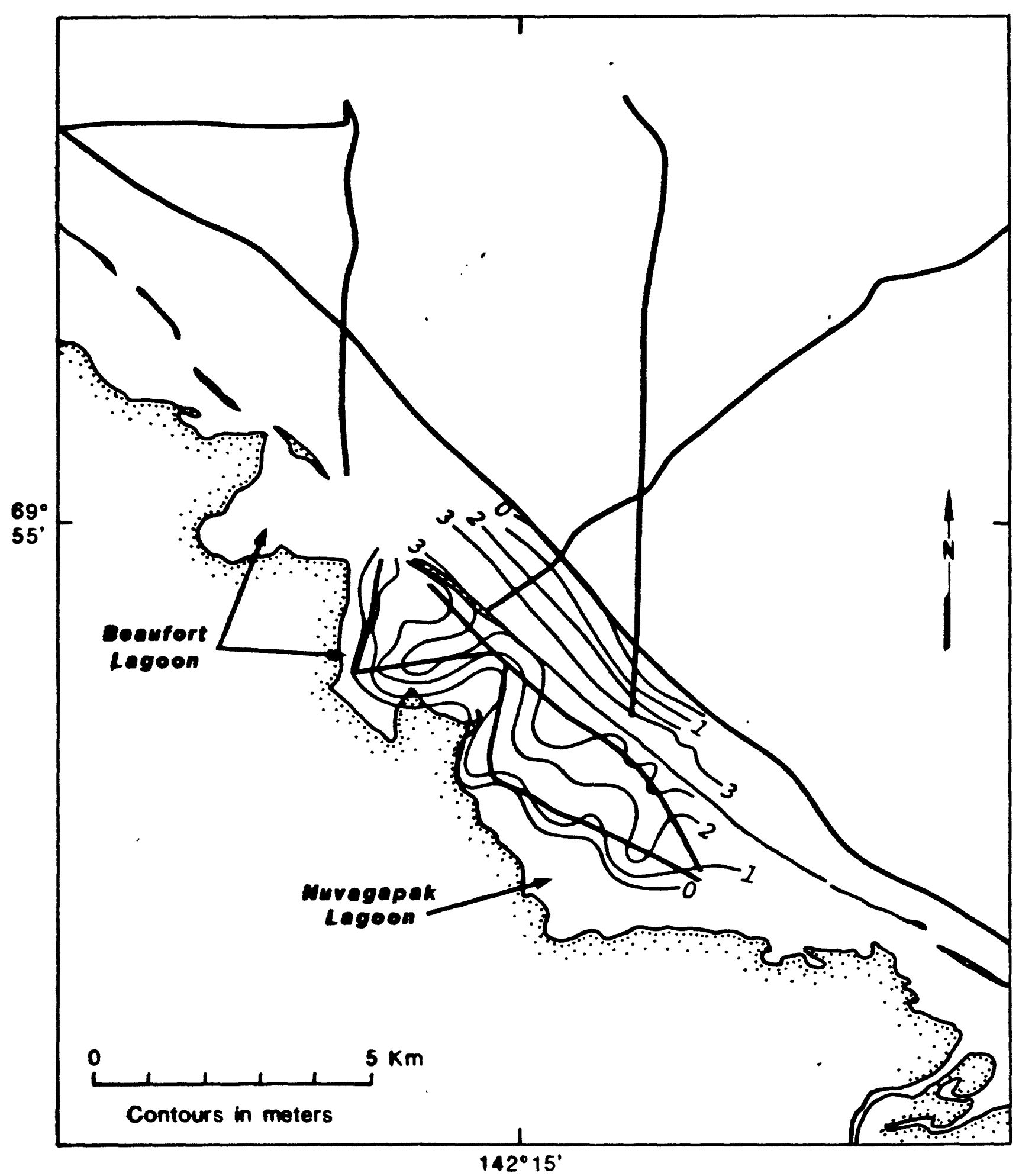

Figure 15. Map showing trackline coverage and thickness of Holocene(?) sediment in Beaufort Lagoon, particularly Nuvagapak Lagoon (see fig. 3). 
Horizon B is acoustically broken in several places by acoustic signatures that have been interpreted as representing gas-charged sediment accumulations. Areal distribution of these "signatures" were plotted along seismic tracks where observed. Too few occurrences were seen to make it possible to determine a pattern of distribution or to allow one to identify "gassy" areas. Most occurrences that were near shore were generally located near entrances to lagoons or were associated with small deltas. These occurrences were few and small in size.

The two largest gas signature areas were observed north of Demarcation Bay (fig. 11). The gas signatures do not appear to be of near-surface origin. Their sources may be at depth and perhaps associated with the broad WNW-ESE channel that occurs between horizons $A$ and $B$ north of Demarcation Bay. The seaward signature, probably defines the NE side of the channel, which may represent an older barrier island complex at depth; these accumulations may have formed from decay of organic matter in lagoonal deposits located inshore (southwest) of the old barriers, or this may be of thermal origin at depth.

\section{AREAL DISTRIBUTION AND ANALYSIS OF HORIZON A}

Sufficient data exist to permit line-to-line correlation and contouring of horizon A from Barter Island to Demarcation Bay (fig. 16). Water depths and depths to horizon A are in milliseconds below sea level. As shown, horizon A slopes seaward and generally has contours which parallel the coastline except for an area north of Demarcation Bay where they turn northeast forming an embayment-like feature. Calculated slopes of the horizon are 11 minutes north of Barter Island, 14 minutes north of Beaufort Lagoon, and 17 and 4 minutes north of Demarcation Bay. Stratigraphic thicknesses can generally be calculated by using approximately 1600 meters/sec sound velocity. This velocity has worked well for' the seismic stratigraphy from Prudhoe Bay to the Canning River (Wolf and others, 1985).

The anomalous embayment on the surface north of Demarcation Bay suggests a depression-like feature or an embayment that existed at the time the surface was formed. It appears that surface drainage at the time of formation of horizon A was directed toward the northwest. The steep 17' nearshore slope probably reflects close proximity to the Brooks Range. For the most part, reflectors above this surface do not suggest tectonic activity (warping through time) as they are generally subparallel to the surface gradient. In general, the acoustic stratigraphy suggests a continuous depositional history, interrupted only twice by widespread erosional cycles represented by horizons A and B and associated cut and fill channels within the section.

Figure 17 shows the locations of two NE-SW profiles constructed to illustrate the relationship of the gradient of horizon A and the adjacent land surface topography. Profile "a" crosses what was earlier described as coastal plain physiography. Profile " $b$ " on the other hand passes through the large fan west of Demarcation Bay and southwest to the base of the Brooks Range. This relationship can be observed on Figure 18. In profile "a", the land gradient below 50 meters altitude essentially parallels horizon $\mathrm{A}$. The profile also suggests that the apparent erosional surface of horizon A crops out at or near the coastline. Horizon B, which is not shown, also crops out near the coastline on some seismic records. These data suggest that sediments deposited onshore during or after those forming horizons $\mathrm{A}$ and $\mathrm{B}$ 


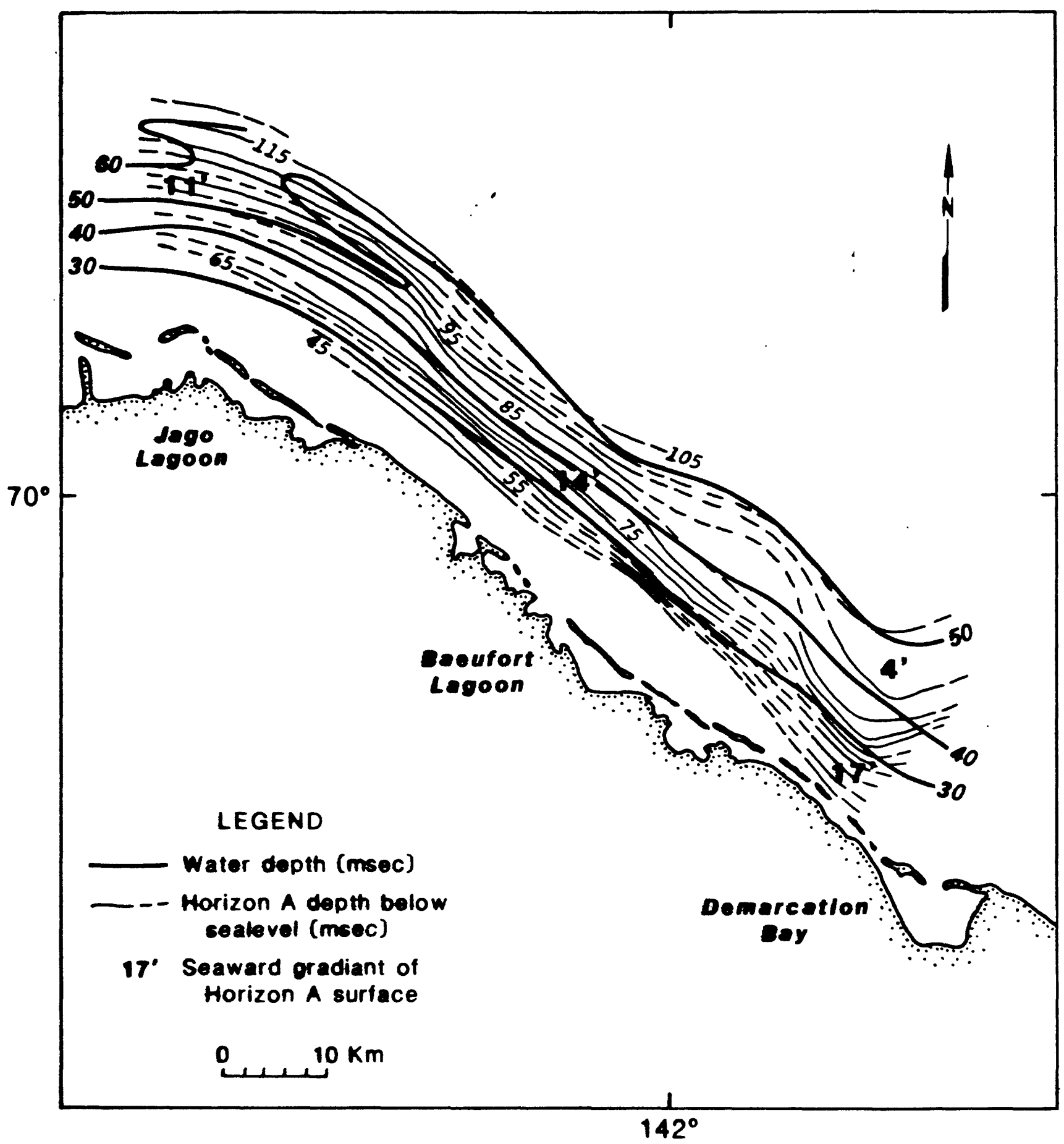

Figure 16. Map showing areal distribution and depth below sea level of Horizon A. 


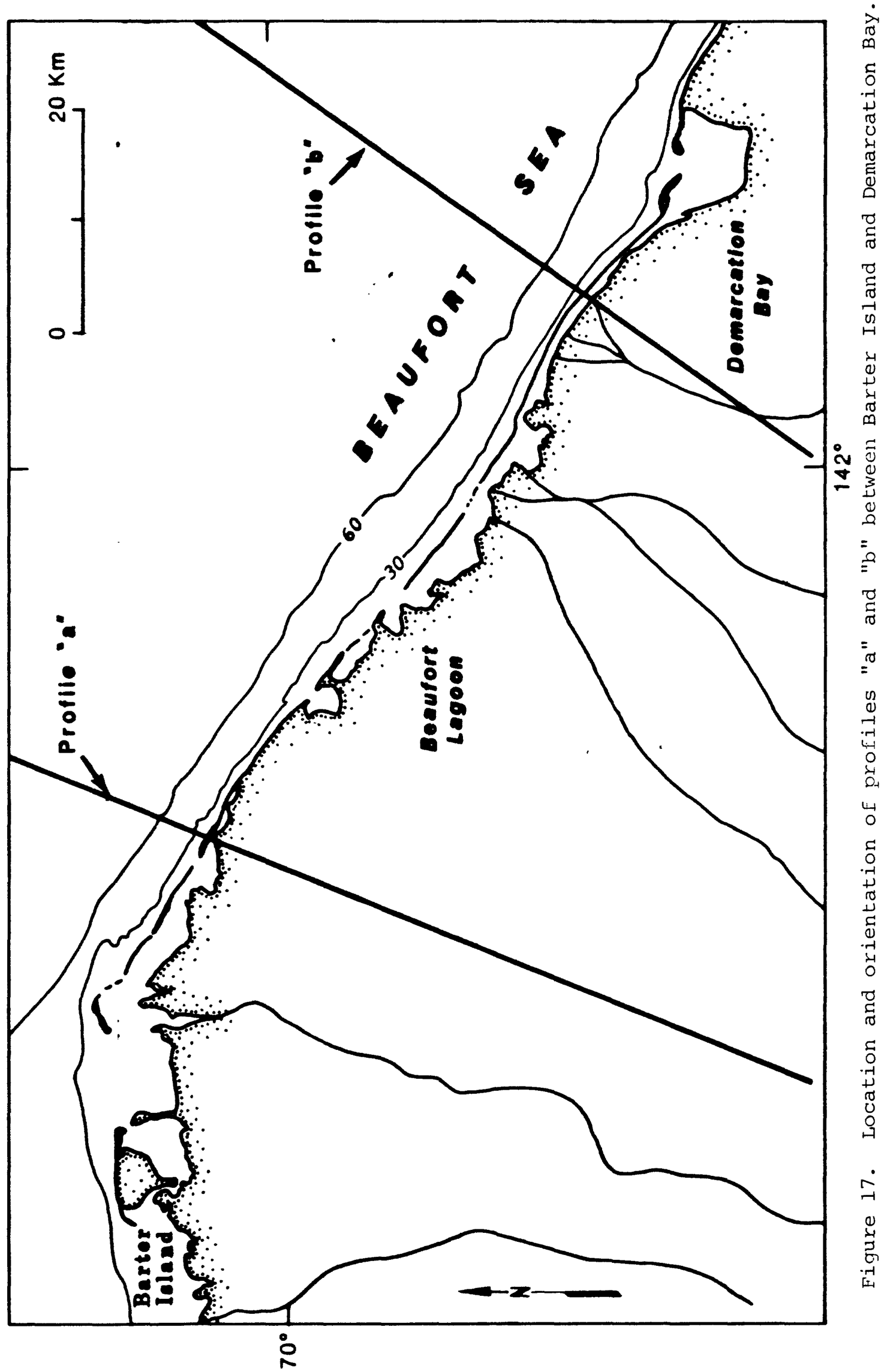




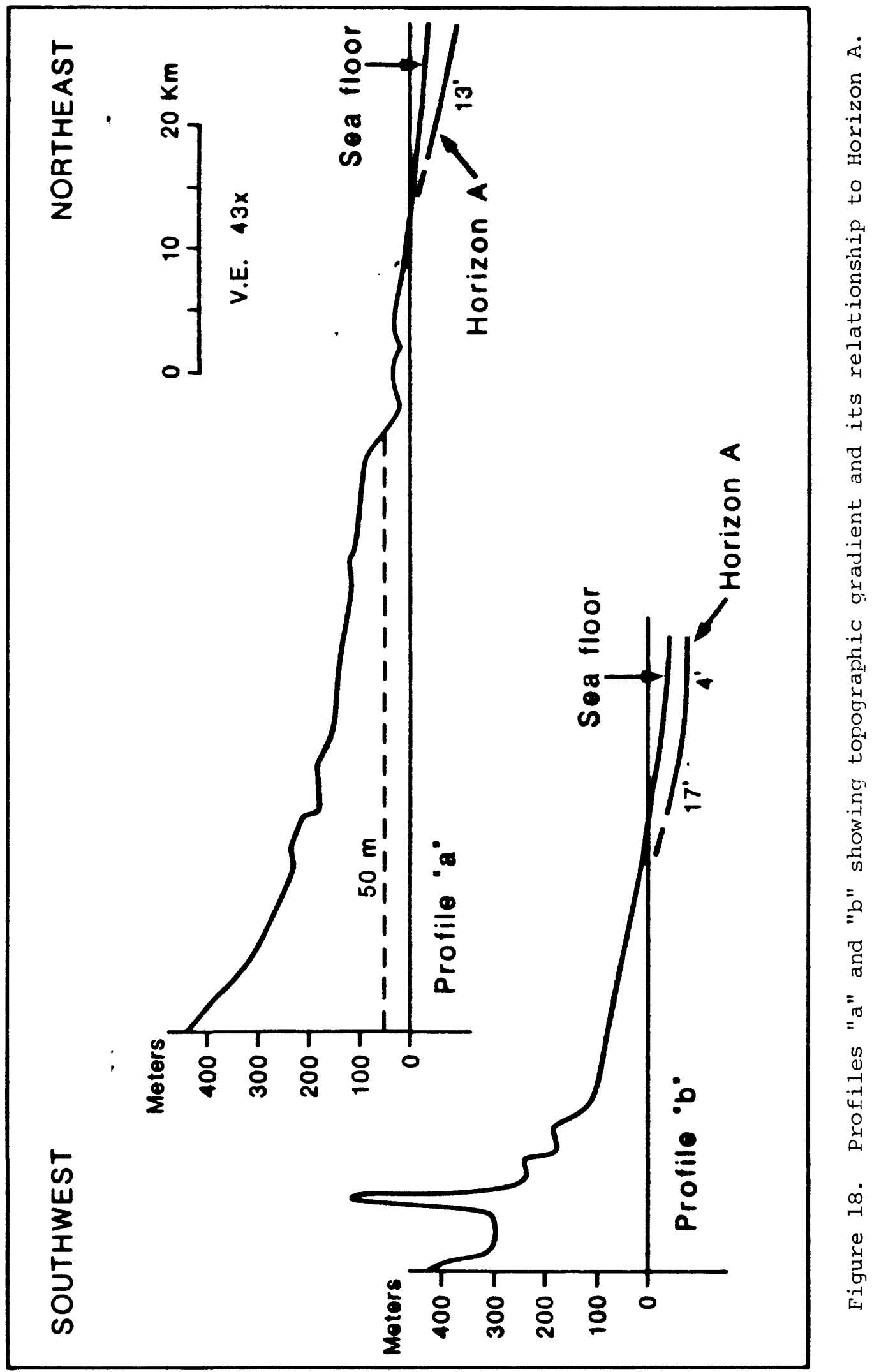


offshore must be very thin and thicken seaward as they approach the inner Beaufort Sea shelf. The sediments at the seafloor of the inner shelf are being actively incised and eroded by ice gouging leaving what appears to be an area of nondeposition or erosion. Therefore, much of the sediment that was deposited on the inner shelf after the time of horizons A and B has been removed from the area. One might conclude that minimal amounts of sediment are being deposited on land and that much of the sediment introduced onto the inner shelf is trapped in lagoons and any sediment that does reach the inner shelf bypasses it in this area. The profiles and the minimal modern sediment accumulations suggests that some of the land features on the coastal plain may, in fact, be old erosional remnants associated with the formation of horizons $A$ and $B$.

The land gradient of Profile " $b$ " is more parallel to that of the seafloor than to the gradient of horizon $A$. This can readily be explained by suggesting that the large fan through which this profile passes is a young feature that is actively passing fine grained sediment toward the Beaufort shelf. If the fan-like structure did not exist, the gradient of horizon $A$ and that of the bedrock underlying the fan surface would be more closely identical as is the case in profile "a".

The 4' gradient in Profile " $b$ " reflects the depression or embayment on horizon A (fig. 12). The 17' gradient of horizon A on this Profile compared to the 13' gradient in Profile " a" clearly reflects the influence on horizon A of the nearby Brooks Range.

\section{INTERPRETATION AND CONCLUSIONS--CANNING RIVER TO BARTER ISLAND AND BARTER ISLAND TO DEMARCATION BAY}

The geometry, depths to horizons $A$ and $A^{\prime}$, and acoustic sediment sequences above $A$ and $A^{\prime}$ to the seafloor, particularly from Barter Island to Demarcation Bay, are similar to features and units described for the area between the Canning River and Prudhoe Bay (Wolf and others, 1985), and the two areas described in this report are thought to have a similar geologic history. In that area sedimentary units were typically deltaic and fluvial outwash, on land and near the coast. These sediments graded into marine fine-grained sediments at the coast and offshore (fig. 19).

In the area between the Canning River and Demarcation Bay, terrestrial deposits in places have prograded out onto the shelf, interfingered with marine deposits, and been subjected to two erosional cycles represented by (1) horizon $A^{\prime}$ and its counterpart horizon A, and (2) horizon B. The seafloor off these areas, like that off the Canning River-Prudhoe Bay area, may also be interpreted as a present day erosional surface with little or no Holocene deposition.

Fan deltas are described as being "alluvial fans that prograde into a standing body of water from an adjacent highland. They are characterized by having gravelly, proximal, braided stream deposits that grade seaward into sandy, distal braided-stream deposits, well laminated sands of the beach-nearshore zone and finally into burrowed shoreface muds" (Wescott and Ethridge, 1980). USGS sediment samples, taken from the fan-like structures along shore and offshore west of Demarcation Bay, show gravel barrier islands and nearshore muddy gravels. These sediments grade laterally into clean and muddy sands with pebbles offshore and to sandy mud and soft mud farther offshore. The steep gradient of the fan, the close proximity of the Brooks Range and the presence of sedimentary textures and structures diagnostic of fan deltas suggest that the large fan-like structure near Demarcation Bay is in fact a fan-delta as described 
in the literature.

The proximal positions of horizons $A$ and $A^{\prime}$ relative to the present coastline, their seaward gradient, depth below sea level, and their relationship to the present adjacent land surface suggests that these horizons may be similar in age and description to surface 3 in the Canning River-Prudhoe Bay area (Wolf and others, 1985).

Horizon A north of Barter Island (fig. 16) projects into the offshore sediment sequence described by Grantz and Dinter (1983) as middle and upper Pleistocene. Borehole data, in the Canning River-Prudhoe Bay area, suggest that surface 3 is approximately $250 \mathrm{Ka}$ (Peggy Smith, personal commun., 1984). These data, and assuming the similarities mentioned earlier for horizons $A, A^{\prime}$ and surface 3 hold true, suggest, therefore, that horizon $A$ and $A^{\prime}$ are middle and upper Pleistocene in age.

Likewise horizon B for the same reasons correlates with surface 4 (fig. 19) in the Canning River-Prudhoe Bay area. From bore hole studies in the western part of that area, surface 4 has an apparent age of $125 \mathrm{ka}$ (Peggy Smith, personal commun., 1984).

A summary of findings of this report is as follows:

(1) By projection of acoustic reflectors onshore, it appears that the arctic coastal plain in this region may actually be an old surface composed largely of erosional remnants masked by thin Holocene(?) sediments including those that form the fan-delta near Demarcation Bay.

(2) The inner shelf appears to be an erosional surface where sealed outcrops have progradational and inner shelf marine depositional histories of pre-Holocene age; this surface is presently being subjected to widespread ice gouging.

(3) The inner shelf may contain records of sediments no older than horizon A (250 ka).

(4) Horizon $\mathbf{A}$ and sediments above have been uplifted and eroded by recent tectonics northwest of Barter Island.

(5) Horizon A ( $-250 \mathrm{ka})$ and horizon B ( $-125 \mathrm{ka})$ record lower sea level stands and the development of unconformities on the inner shelf.

(6) Post horizon B sediments reach a maximum thickness of 15 meters, but the age of the youngest sediments is unknown.

(7) Holocene sediments are believed to be restricted to near shore barrier islands and lagoons, and those sediments that are being introduced onto the inner shelf are bypassing the area.

(8) Ridges offshore are mostly erosional remnants possibly left from subaerial erosion from the last sea level lowstand. Some ridges in Camden Bay are constructional and appear to be moving shoreward.

(9) Few occurrence of gas-charged sediments were noted. The largest accumulations were in two areas north of Demarcation Bay on the inner shelf. 


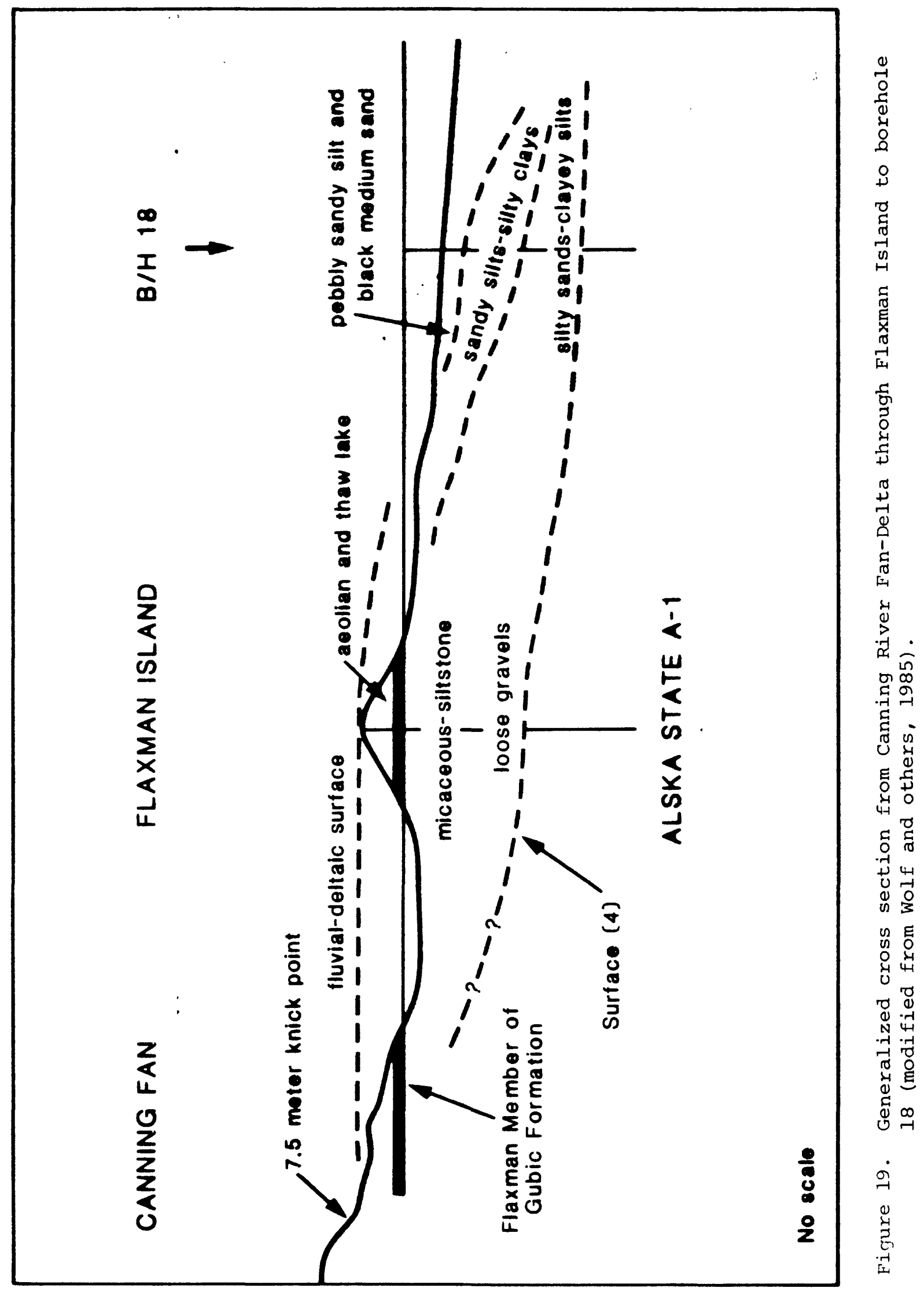




\section{REFERENCES CITED}

Barnes, P.W., Reimnitz, Erk, Kempema, E.W., Minkler, P., Ross, C.R., 1980, Marine Geologic Studies in the Beaufort Sea, Alaska, 1979; data type, location, and records obtained: U.S. Geological Survey Open-File Report 80-603, 4 p.

Grantz, Arthur, and Dinter, D.A., and Baswas, N.N., 1983a, Map, cross sections, and chart showing Late Quaternary faults, folds, and eaand chart showing Late Quaternary faults, folds, and earthquake epicenters in the Alaskan Beaufort Shelf; Miscellaneous Investigation series, U.S. Geological Survey and Geophysical Institute, University of Alaska, map I-1182-C.

Grantz, Arthur, Dinter, D.A., and Baswas, N.N., 1983b, Holocene faulting, warping, and earthquake epicenters on the Beaufort shelf north of Alaska: U.S. Geological Survey Map I-1189-C, with text, cross sections, and correlation chart, 3 map sheets, scale $1: 500,000,7 \mathrm{p}$.

Graves, S.M., Reimnitz, Erk, and Barnes, P.W., 1984, A summary of U.S. Geological Survey geological data collected in the Beaufort Sea, Alaska; 1983, U.S. Geological Survey Open-File Report 84-117, 13 p.

Kempema, E.W., Barnes, P.W., Reimnitz, Erk, Asbury, J.L., and Rearic, D.M., 1983, A summary of U.S. Geological Survey Marine Geological Data collected in the Beaufort sea, Alaska, 1982: U.S. Geological Survey Open-File Report 83-493, 2 rolls microfilm, 9 p.

Kempema, E.W., Reimnitz, Erk, and Barnes, P.W., 1981, Marine geologic studies in the Beaufort Sea, Alaska, 1980; data type, location, records obtainèd, and their availability: U.S. Geological Survey Open-File Report 81-241, 4 p.

Minkler, P.W., Reimnitz, Erk, and Barnes, P.W., 1982, A summary of U.S. Geological Survey marine geologic data collected in the Beaufort Sea, Alaska, July-August 1981: U.S. Geological Survey Open-File Report 82-586, 9 p.

Reimnitz, Erk and Maurer, D., 1978, Stamuki Shoals of the Arctic - Some observations from the Beaufort Sea: U.S. Geological Open-Report 78-666, 17 p.

Reimnitz Erk, Barnes, P.W., Rearic, D.M., Minkler, P.W., Kempema, E.W., and Reiss, T.E., 1982, Marine geological investigations in the Beaufort Sea in 1981 and preliminary interpretation of the region from the Canning River to the Canadian Border: U.S. Geological Survey Open-File Report 82-974, 64 p.

Vail, P.R. and others, 1976 and 1977, Various versions of short course notes, stratigraphic interpretation of seismic data, AAPG school, Tulsa, Oklahoma.

Vail, P.R. and others, 1977, Seismic stratigraphy and global changes in sea level in seismic stratigraphy, AAPG Memorandum 26, Tulsa, Oklahoma, 516 p. 
Walker, D.A., Acevedo, W., Everett, K.R., Gados, L., Brown, J., and Webber, P.J., 1982, LANDSAT assisted environmental mapping in the Arctic National Wildlife Refuge, Alaska, CRREL Report 82-27, 59 p.

Wescott, W.A. and Ethridge, F.G., 1980, Fan delta sedimentology and tectonic setting, Yallah Fan Delta, Southeast Jamaica, American Association of Petroleum Geologists, v. 64 , no. 3, p. 374-399.

Wolf, S.C., Reimnitz, Erk, and Barnes, P.W., 1985, Pleistocene and Holocene seismic stratigraphy between the Canning River and Prudhoe Bay, Beaufort Sea, Alaska: U.S. Geological Survey Open-File Report 85-549, 50 p. 